\title{
Petrogenesis of the Permian Intermediate-Mafic Dikes in the Chinese Altai, Northwest China: Implication for a Postaccretion Extensional Scenario
}

\author{
Keda Cai, ${ }^{1, \star}$ Min Sun, ${ }^{2}$ Bor-ming Jahn, ${ }^{3}$ Wenjiao Xiao, ${ }^{1}$ Xiaoping Long, ${ }^{4}$ \\ Huayong Chen, ${ }^{5}$ Xiaoping Xia, ${ }^{5}$ Ming Chen, ${ }^{2}$ and Xiangsong Wang ${ }^{1}$
}

\begin{abstract}
1. Xinjiang Research Centre for Mineral Resources, Xinjiang Institute of Ecology and Geography, Chinese Academy of Sciences, Urumqi 830011, China; 2. Department of Earth Sciences, University of Hong Kong, Pokfulam Road, Hong Kong, China; 3. Department of Geosciences, National Taiwan University, Taipei 106, Taiwan; 4. State Key Laboratory of Continental Dynamics, Department of Geology, Northwest University, Northern Taibai Street 229, Xi'an 710069, China; 5. Key Laboratory of Isotope Geochronology and Geochemistry, Guangzhou Institute of Geochemistry, Chinese Academy of Sciences, Guangzhou 510640, China
\end{abstract}

\begin{abstract}
A B S T R A C T
The Central Asian Orogenic Belt is a long-lived accretionary orogen, and the late Paleozoic has been considered to be a critical period for the terminal amalgamation of its three tectonic collage systems. However, the exact timing of amalgamation and the geological process of such a huge accretionary orogenic belt are poorly understood. This study presents new geochronological and geochemical data for Permian intermediate-mafic dikes in the Chinese Altai, a key region between the Mongolian and the Kazakhstan collage systems. According to mineral assemblages and petrographic textures, the intermediate-mafic dikes can be categorized as gabbronorite and quartz diorite. The gabbronoritic and quartz dioritic dikes have zircon U-Pb ages of $276.7 \pm 2.9$ and $273.2 \pm 4.3 \mathrm{Ma}$, respectively. The gabbronorites are characterized by low $\mathrm{SiO}_{2}(47.1-51.3 \mathrm{wt} \%)$ and high $\mathrm{MgO}(5.33-8.46 \mathrm{wt} \%)$, together with medium $\mathrm{Cr}(71.2-95.7 \mathrm{ppm})$ and $\mathrm{Ni}(80.6-192 \mathrm{ppm})$ contents. Geochemical modeling indicates that the parental magma was possibly contaminated by $4 \%-12 \%$ crustal materials. Zircon $\varepsilon_{\mathrm{Hf}}(t)(+13.2$ to +16.7$)$ and whole-rock $\varepsilon_{\mathrm{Nd}}(t)(+4.9$ to $+6.1)$ values as well as moderate $\mathrm{Sm} / \mathrm{Yb}$ ratios (1.75-1.89) imply that the parental magma might have originated from a depleted mantle source dominated by spine lherzolite. In contrast, the quartz diorites exhibit higher $\mathrm{SiO}_{2}(57.3-$ $58.3 \mathrm{wt} \%)$ and lower whole-rock $\varepsilon_{\mathrm{Nd}}(t)(\sim+2.5)$ and zircon $\varepsilon_{\mathrm{Hf}}(t)(+9.1$ to +14.4$)$ values, implying that they have a magma source unlike the depleted mantle of the gabbronorites. The parental magma may be derived from mafic lower crust. The quartz diorites have high $\mathrm{Y}(>39.8 \mathrm{ppm})$ and heavy rare earth element (e.g., $\mathrm{Yb}>3.64 \mathrm{ppm})$ concentrations as well as low $\mathrm{Sr} / \mathrm{Y}(<12)$ ratios, consistent with geochemical fingerprints of a magma reservoir at shallow depths $(<10 \mathrm{~kb})$. Major element compositions of the quartz diorites are comparable to those of intermediate liquids generated by $\sim 40 \%$ partial melting of alkali-enriched basaltic rocks at conditions of $T=1050^{\circ}-1100^{\circ} \mathrm{C}$ and $P=8 \mathrm{kbar}$. Such a high geothermal gradient is inferred to be a consequence of intraplating and/or underplating of hot basaltic magmas in an extensional setting, which may shed light on the ubiquitous tectonic scenario after amalgamation of tectonic collages.
\end{abstract}

Online enhancements: supplementary tables.

\section{Introduction}

The Central Asian Orogenic Belt is one of the largest and longest-lived accretionary orogenic collages on earth, representing a typical region of massive

Manuscript received July 2, 2015; accepted February 10, 2016; electronically published June 20, 2016.

* Author for correspondence; e-mail: caikd_117@hotmail.com. continental crust growth (Sengör et al. 1993; Sengör and Natal'in 1996; Jahn et al. 2000a, 2000b; Jahn 2004; Windley et al. 2007). Its development is believed to be a consequence of the incorporation of numerous allochthonous materials, such as island arcs, seamounts, subduction-accretion complexes, ophiolites, and microcontinents (Khain et al. 2002;

[The Journal of Geology, 2016, volume 124, p. 481-500] (c) 2016 by The University of Chicago. All rights reserved. 0022-1376/2016/12404-0004\$15.00. DOI: 10.1086/686464 
Windley et al. 2002, 2007; Kovalenko et al. 2004; Xiao et al. 2004; Kröner et al. 2011, 2014; Wilhem et al. 2012; Xiao and Santosh 2014; Zhang et al. 2015). These diverse components merged into three independent collage systems in the early Paleozoic, namely, the Mongolian, Kazakhstan, and Tarim-North China collage systems (fig. 1; Xiao et al. 2015). However, little is known about the final tectonic process and timing of their mutual convergence in the late Paleozoic.
The Chinese Altai is situated along the southwestern margin of the Mongolian collage system and is juxtaposed with the Kazakhstan collage system to the south (fig. 1). Because of this tectonic position, the Chinese Altai is considered to be a key region to study the convergent processes and amalgamation between the Mongolian and Kazakhstan collage systems. Previous investigations documented that the Chinese Altai was a subductionaccretion complex built on the margin of Mongolian

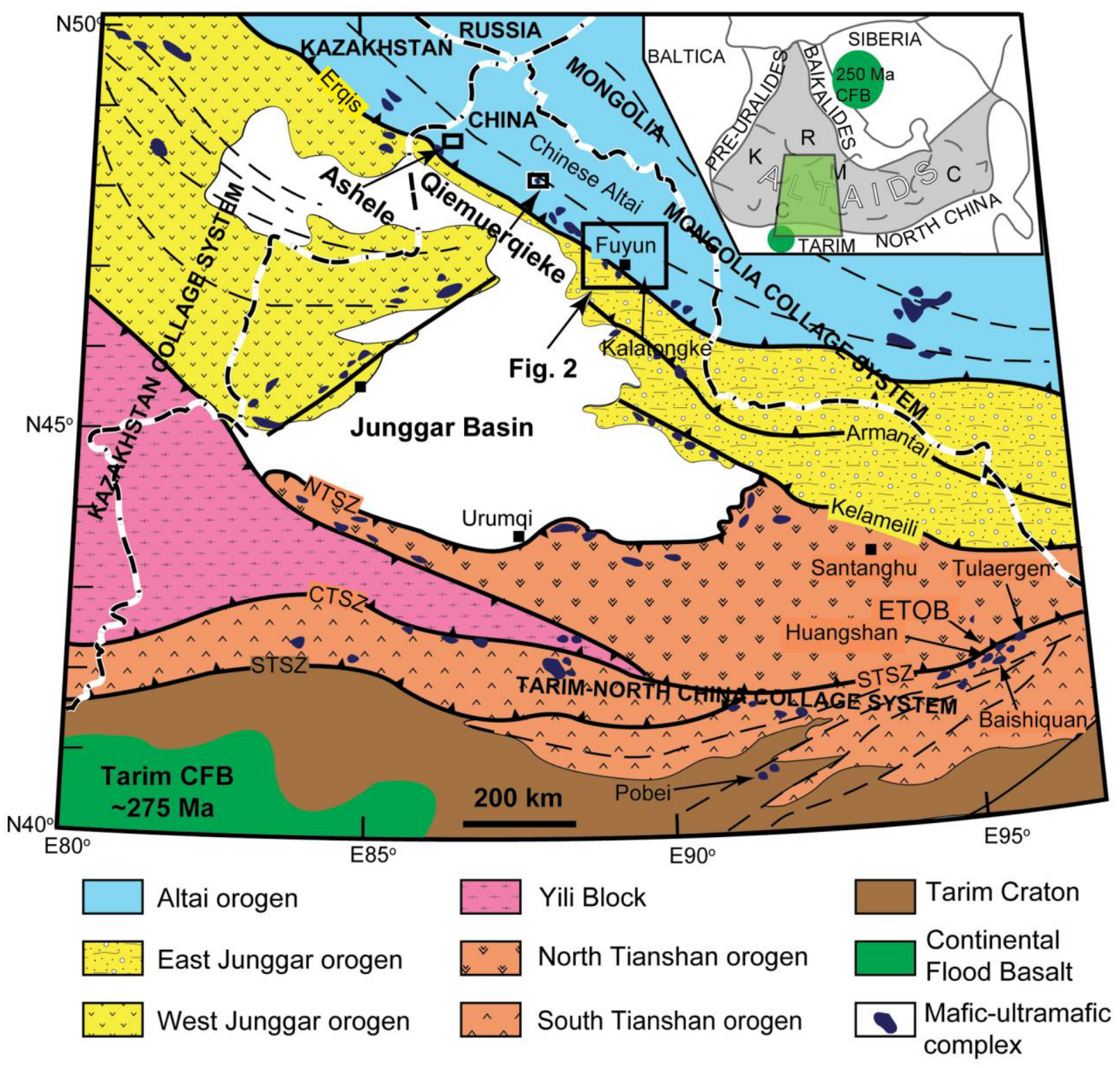

Figure 1. Simplified geological map of the western Central Asian Orogenic Belt, showing the study area and adjacent regions. This is modified after Ren et al. (1999), Pirajno et al. (2008), and Wan et al. (2013). ETOB, East Tianshan ore belt; NTSZ, CTSZ, STSZ, North, Central, and South Tianshan suture zones, respectively. Box indicates the study area (Fuyun region). 
collage systems in the early Paleozoic (Long et al. 2007, 2010; Sun et al. 2008; Xiao et al. 2008, 2009; Cai et al. 2011c, 2014a). However, there is much debate on its tectonic scenario in the Carboniferous to Permian, a critical period not only for its final amalgamation but also for the formation of major ore deposits in the region (Han et al. 2004; Gao and Zhou 2013). Several competing tectonic models have been recently proposed for the late Paleozoic tectonic evolution of the Chinese Altai, including oceanic subduction (Chen et al. 2006a, 2006b; Xiao et al. 2011; Wan et al. 2013; Zhang et al. 2015), postcollisional extension (Han et al. 2004; Song and Li 2009; Zhang et al. 2009; Su et al. 2011; Tong et al. 2012, 2014; Gao and Zhou 2013), slab break-off(Lietal.2012; Gao andZhou 2013), and mantle plume (Mao et al. 2008; Pirajno et al. 2008; Tong et al. 2014; Zhang et al. 2014). Therefore, more systematic research should be undertaken to unravel the tectonothermal events that have determined the tectonic evolution of the region. This study reports zircon $\mathrm{U}-\mathrm{Pb}$ and $\mathrm{Hf}$ isotopic data and wholerock geochemistry for the Permian immediate-mafic rocks from the south margin of the Chinese Altai, aiming to understand their petrogenesis and tectonic implications.

\section{Geological Background}

The Central Asian Orogenic Belt covers an immense area that extends from the Ural Mountains on the west to the Pacific coast on the east. It is bounded by the Siberian Craton to the north and the TarimNorth China Cratons to the south (fig. 1; Zonenshain et al. 1990; Mossakovsky et al. 1993; Sengör et al. 1993; Sengör and Natal'in 1996; Jahn et al. 2000a, 2000b; Windley et al. 2002, 2007; Jahn 2004). This huge accretionary orogenic belt can be subdivided into three early Paleozoic collage systems: the Mongolian collage system, the Kazakhstan collage system, and the Tarim-North China collage system (Xiao et al. 2015). The Mongolian and Kazakhstan collage systems were bent into two separate oroclines (Xiao et al. 2004, 2008, 2010, 2013, 2015; Levashova et al. 2010, 2011), which were duplicated by slicing and striking (Sengör et al. 1993; Yakubchuk 2004) and bounded to the south by the Tarim-North China collage system (fig. 1).

The Mongolian collage system was likely a Devonian-Carboniferous ribbon-like archipelago involving numerous island arcs and subduction accretionary complexes (Badarch et al. 2002; Xiao et al. 2004, 2015; Windley et al. 2007; Wilhem et al. 2012). This collage was bent to form the Mongolian orocline, probably in Permian to Triassic time, as a result of the collision with the Tarim-North China collage system (Lehmann et al. 2010; Bernard Edel et al. 2014; Xiao et al. 2015). The Altai Mountain Range constitutes the southwestern margin of the Mongolian orocline and extends ca. $2500 \mathrm{~km}$ from Russia, through Kazakhstan and China to southwestern Mongolia (Cai et al. 2011c, 2014a, 2014b). The Chinese Altai occupies the central portion of the Altai Mountain Range and is subdivided into the North Altai, Central Altai, Qionghuer Domain, and South Altai (BGMRX 1993; Windley et al. 2002; Long et al. 2007, 2010; Cai et al. 2010, 2011c, 2012a). The North Altai is mainly composed of late Devonian-early Carboniferous neritic clastic sedimentary rocks, arc volcanic rocks, and greenschists. The Central Altai is underlain by thick turbiditic and pyroclastic sedimentary sequences, most of which were deformed and folded with steep axial planes. Voluminous granitic rocks and several mafic-ultramafic stocks intruded these sedimentary sequences. The Qionghuer Domain contains late Silurian sedimentary rocks (Kulumutu Group), Early Devonian arc pyroclastic rocks (Kangbutiebao Formation), and middle Devonian turbidites (Altai Formation). Rocks of this domain were metamorphosed to greenschist or upper amphibolite facies and locally to granulite facies. The South Altai consists of Devonian fossil-bearing sedimentary rocks and late Carboniferous volcaniclastic rocks that underwent greenschist to amphibolite facies metamorphism (He et al. 1990; Windley et al. 2002; Cai et al. 2011a, 2011b, 2011c, 2012a).

To the south, the Chinese Altai is separated by the Erqis Fault-a large-scale $(1000 \mathrm{~km})$ sinistral strike-slip fault-from the Junggar composite terrane, which consists of East Junggar, West Junggar, and Junggar basins (fig. 1). The East Junggar includes NW-striking Dulate and Yemaquan island arcs, which are separated by the highly deformed and dismembered Armantai ophiolite belt (Xiao et al. 2004, 2009; Long et al. 2012; Cai et al. 2014b). The Dulate arc is situated along the north side of the Armantai ophiolite and includes Devonian-Carboniferous volcanic rocks, such as picrite, boninite, high- $\mathrm{Mg}$ andesite, and Nb-rich basalt (Zhang et al. 2003, 2004). The Yemaquan arc is located to the south of the Armantai ophiolite and is dominated by OrdovicianCarboniferous clastic rocks and carbonates, with subordinate volcaniclastic rocks (Xiao et al. 2009, 2011; Long et al. 2012). A plagiogranite from the Armantai ophiolitic mélange yielded a SHRIMP zircon age of $503 \pm 7 \mathrm{Ma}$ (Xiao et al. 2009). The Junggar Basin is a large petroliferous basin covered by several kilometers of Mesozoic sedimentary rocks, and its basement nature remains a subject of debate (Carroll et al. 
1990; Han et al. 1999; Xu et al. 2013, 2015). The West Junggar constitutes a portion of the Kazakhstan collage system that formed by multiple accretions of seamounts, intra-ocean arcs, ophiolite fragments, and subduction complexes during the Middle Cambrian to Carboniferous (Carroll et al. 1995; Chen and Jahn 2004; Han et al. 2004; Jahn 2004; Xiao et al. 2004, 2009). The Kazakhstan collage system includes the Chingiz arc, the Kokchetav microcontinent, and the North Tianshan-Yili arc and is interpreted to occur as a long composite arc in the early Paleozoic. This composite arc was converted to the Kazakhstan orocline through bending in the late Paleozoic (Xiao et al. 2015). The northern limb of the Kazakhstan orocline is represented by the Chingiz arc that extends almost to the Erqis Fault in the north, and the southern limb is denoted by the Yili arc. The Kazakhstan orocline was proposed to have an association with ridge subduction in the late Carboniferous in the West Junggar (Geng et al. 2009; Xiao et al. 2010, 2015; Yin et al. 2010; Choulet et al. 2012; Ma et al. 2012).

\section{Regional Geology and Sample Descriptions}

The south Chinese Altai is characterized by widespread occurrences of magmatic rocks and complex fault systems. The study area is bracketed by the Fuyun fault in the east, the Kurti fault in the southwest, and the Abagong fault in the north (fig. 2). The Fuyun fault has typical characteristics of ductile shear deformation, indicated by S-C fabrics, asymmetric folding, and augen structure. The ductile shear zone is characterized by steeply NE-dipping penetrative mylonitic foliation and gently plunging subhorizontal stretching lineation. The Kurti and Abagong faults are considered to be two separate branches of an imbricated thrust fault system (fig. 2), and they occur broadly parallel to the orientation of the Irtish thrust in this area. The majority of magmatic intrusions were emplaced in the Devonian (Wang et al. 2006; Yuan et al. 2007; Cai et al. 2010, 2011a, 2011b, 2011c); however, intermediate and mafic magmatic rocks, the focus of this study, were mainly emplaced in the Permian. The Permian magmatic rocks are distributed along two fault systems (fig. 2). The northern belt is along the NNW-SSE-trending Fuyun fault zone, and the rocks of this belt intruded the Ordovician Habahe Group. The southern belt is along the NW-SE-trending Kurti fault zone, and the rocks of this belt intruded the Silurian and Devonian strata. Field investigations show that the studied intermediate and mafic dikes vertically intruded the granitoid rocks and paragneisses, and their width varies from several meters to tens of meters (fig. 2). The dikes are fresh, with much weaker deformation than the surrounding granitoid rocks and paragneisses. Based on the mineral assemblages and petrographic textures, the intermediate-mafic dikes can be categorized as gabbronorite and quartz diorite, respectively.

The gabbronorite consists of plagioclase (40$50 \mathrm{vol} \%$ ), orthopyroxene (20-30 vol\%), and clinopyroxene (10-20 vol\%), with minor contents of magnetite, Cr-spinel, and ilmenite (fig. $3 b$ ). Plagioclase grains are euhedral to subhedral and $1-5 \mathrm{~mm}$ in length, while clinopyroxene, orthopyroxene, and other minerals are subhedral to anhedral. Clinopyroxene and orthopyroxene commonly show variable chloritization, and plagioclase shows the features of sericitization and kaolinitization. Quartz diorite consists of quartz (10-20 vol\%), plagioclase (50-60 vol\%), and hornblende (20-30 vol\%), with minor apatite, magnetite, and zircon. The quartz dioritic rocks have a granular texture characterized by interlocking hornblende and plagioclase (fig. 3d). Plagioclase grains are subhedral to anhedral and are $0.5-2 \mathrm{~mm}$ in length. Anhedral to subhedral hornblende has irregular shapes and is embedded in the interstices among plagioclase grains. Anhedral quartz grains have sizes ranging from 0.2 to $1.0 \mathrm{~mm}$ in length.

\section{Analytical Methods}

Zircon Separation and Cathodoluminescence Imaging. After sample crushing, zircons were separated by standard heavy liquid and magnetic techniques. Crystal grains from the $>25 \mu \mathrm{m}$ nonmagnetic fractions were handpicked and mounted on adhesive tape, enclosed in epoxy resin, and polished to about half of their thickness. Cathodoluminescence images were taken, using a JXA-8100 electron probe microanalyzer with a Mono CL3 cathodoluminescence system for high-resolution imaging and spectroscopy, at the Guangzhou Institute of Geochemistry, Chinese Academy of Sciences, to investigate internal structures and to choose potential target sites for $\mathrm{U}-\mathrm{Pb}$ and Hf analyses.

Zircon U-Pb Dating. Zircon U-Pb isotopic analyses were performed at the Department of Earth Sciences, University of Hong Kong. A 193-nm excimer laser ablation system (Resolution M-50) was used in connection with a Nu Plasma multicollector inductively coupled plasma mass spectrometer (MC-ICPMS). Helium gas, which carries the laser-ablated sample aerosol from sample cell, was mixed with argon carrier gas and nitrogen as additional diatomic gas to enhance sensitivity and finally flows into the MCICP-MS torch for analysis. The detailed analytical procedure is described by Xia et al. (2011). The majority of the analyses were conducted with a beam 

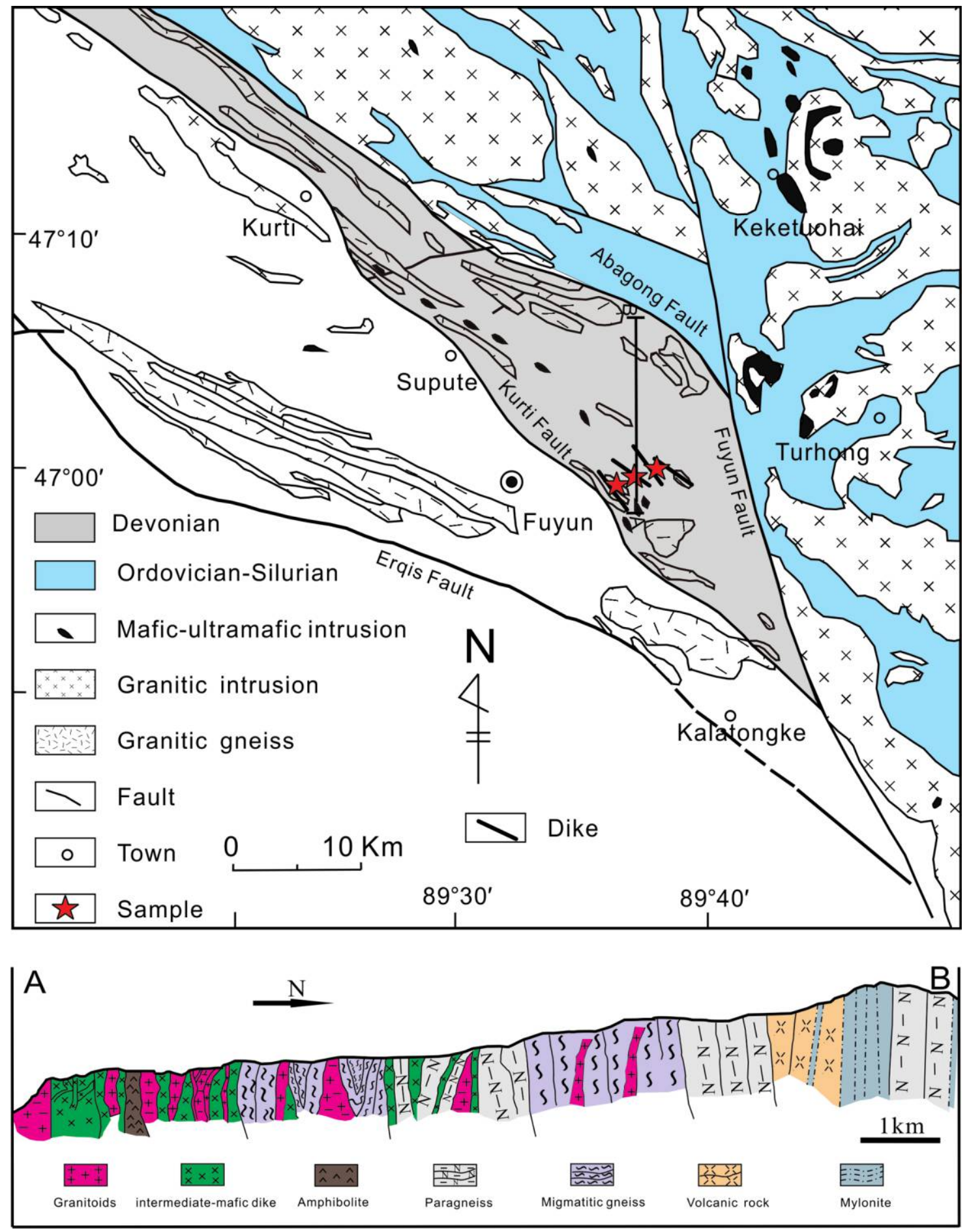

Figure 2. Distributions of dikes and mafic-ultramafic intrusions in the Fuyun area $(A)$ and cross section of the study area (B; after Cai et al. 2012a).

diameter of $30 \mu \mathrm{m}$, repetition rate of $5 \mathrm{~Hz}$, and energy of $\sim 5 \mathrm{~J} / \mathrm{cm}^{2}$ per pulse. Zircons 91500 and GJ-1 were used as the external standards for calibration. The mass fractionation correction and isotopic results were calculated by ICPMSDataCal (ver. 7.0; Liu et al.
2008). A common $\mathrm{Pb}$ correction was applied to all measured ratios using the interference and background-corrected ${ }^{204} \mathrm{~Pb}$ signal intensity, following the approach of Andersen (2002). Age calculation and concordia plots were processed using ISOPLOT 3.0 

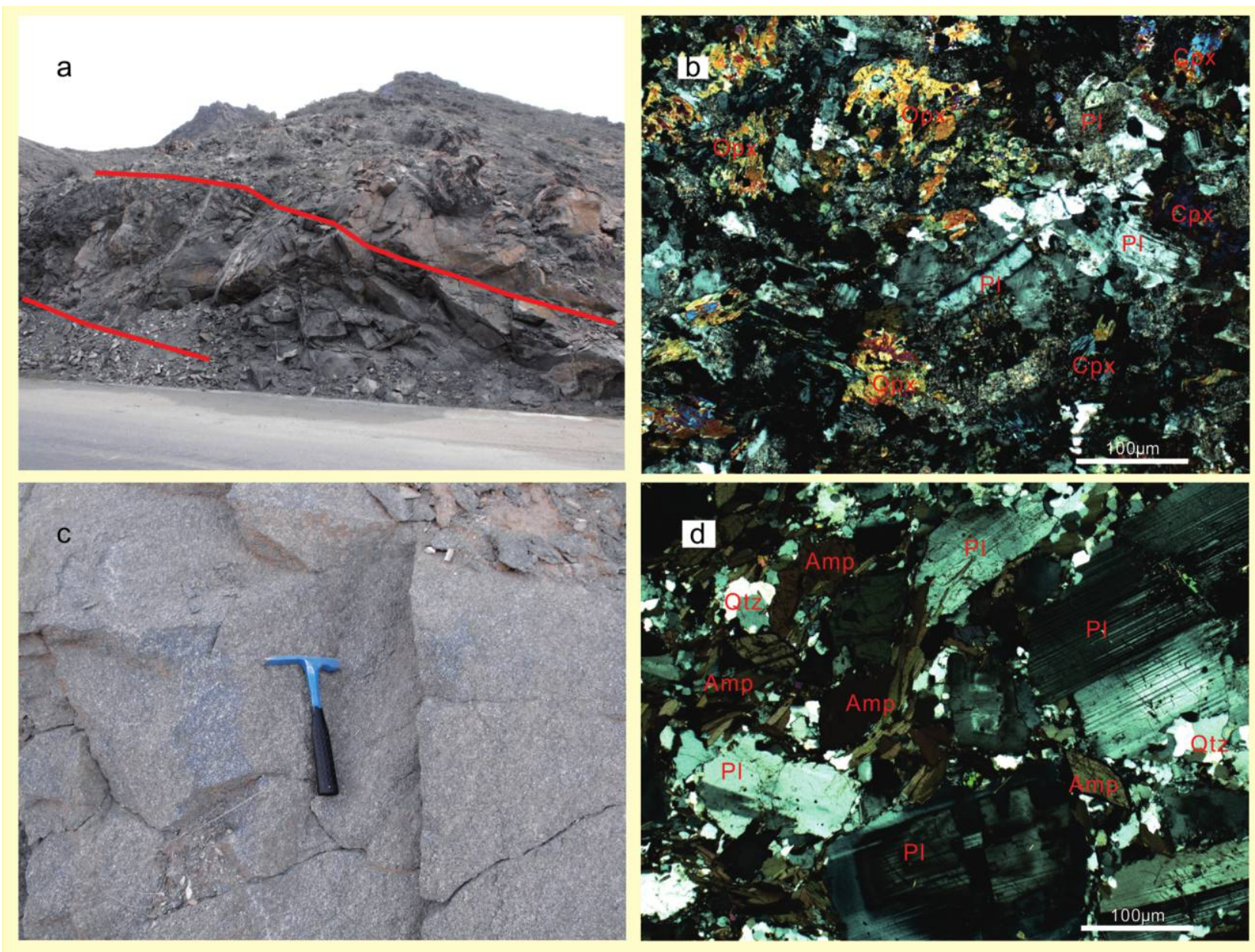

Figure 3. Field photo of the gabbronoritic dikes $(a)$, microscope photo of the thin section of the gabbronoritic rock $(b)$, field photo of the quartz dioritic dikes $(c)$, and microscope photo of the thin section of the quartz diorites $(d)$ in the Fuyun region. Pl, plagioclase; Qtz, quartz; Cpx, clinopyroxene; Opx, orthopyroxene; Amp, amphibole.

(Ludwig 2003). Individual analyses are presented with $1 \sigma$ error in table S1 (tables S1-S5 available online) and in concordia diagrams (fig. 5). Uncertainties of mean age calculations are quoted at the $95 \%$ level. ${ }^{206} \mathrm{~Pb} / 238 \mathrm{U}$ ages are used for grains $<1.0 \mathrm{Ga}$, and ${ }^{207} \mathrm{~Pb} / 206 \mathrm{~Pb}$ ages are used for grains $>1.0 \mathrm{Ga}$, according to Black et al. (2003). The U-Pb isotopic data are shown in table S1.

Zircon Lu-Hf Isotopic Analyses. Zircon Hf isotope analyses were performed using the laser ablation system Resolution M-50, attached to a Nu Plasma high-resoluion MC-ICP-MS, at the Department of Earth Sciences, the University of Hong Kong. A spot size of $40 \mu \mathrm{m}$ was used for most analyses and the ablation spot for $\mathrm{Hf}$ isotope analysis was sited at the same cathodoluminescence domain for the U-Pb dating. The standard zircon 91500 was used as a reference standard, with a weighted mean ${ }^{176} \mathrm{Hf} /{ }^{177} \mathrm{Hf}$ ratio of $0.282298 \pm 6(2 \sigma, n=50)$, similar to the recommended ${ }^{176} \mathrm{Hf} /{ }^{177} \mathrm{Hf}$ ratio of $0.282306 \pm 10$
(Woodhead et al. 2004). Detailed instrumental settings and analytical procedures were as described by Xia et al. (2011). All Hf isotope data were calculated using the decay constant of $1.865 \times 10^{-11} \mathrm{yr}^{-1}$ (Schärer et al. 2001). The chondritic values of ${ }^{176} \mathrm{Hf} /{ }^{1{ }^{17}} \mathrm{Hf}=$ 0.282772 and ${ }^{176} \mathrm{Lu} /{ }^{177} \mathrm{Hf}=0.0332$ (Blichert-Toft and Albarede 1997) were used for the calculation of $\varepsilon_{\mathrm{Hf}}(\mathrm{t})$ values. The depleted mantle Hf model ages $\left(\mathrm{T}_{\mathrm{DM}}\right)$ were calculated using the measured ${ }^{176} \mathrm{Lu} /{ }^{177} \mathrm{Hf}$ ratios of zircon, assuming that the depleted mantle reservoir has a linear growth from ${ }^{176} \mathrm{Hf} /{ }^{177} \mathrm{Hf}=0.279718$ at $4.55 \mathrm{Ga}$ to 0.283250 at present, with a ${ }^{176} \mathrm{Lu} /{ }^{177} \mathrm{Hf}$ value of 0.0384 (Griffin et al. 2000). The Lu-Hf isotopic results are presented in table S2.

Major and Trace Element Analyses. Major oxides were determined by wavelength-dispersive $\mathrm{X}$-ray fluorescence spectrometry on fused glass beads, using a Rigaku RIX 2000 X-ray fluorescence spectrometer at the Guangzhou Institute of Geochemistry, Chi- 


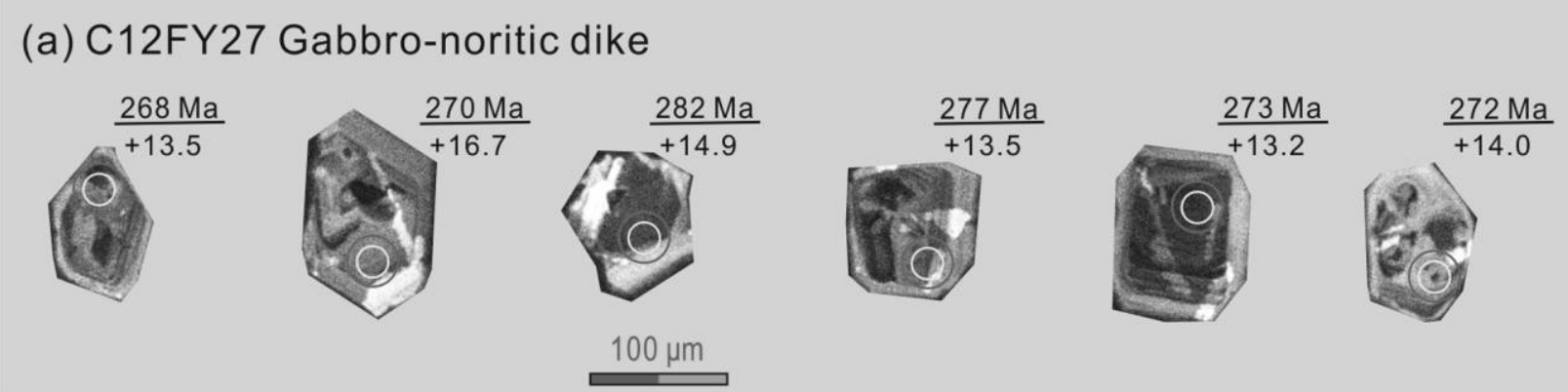

(b) C12FY15 Quartz dioritic dike
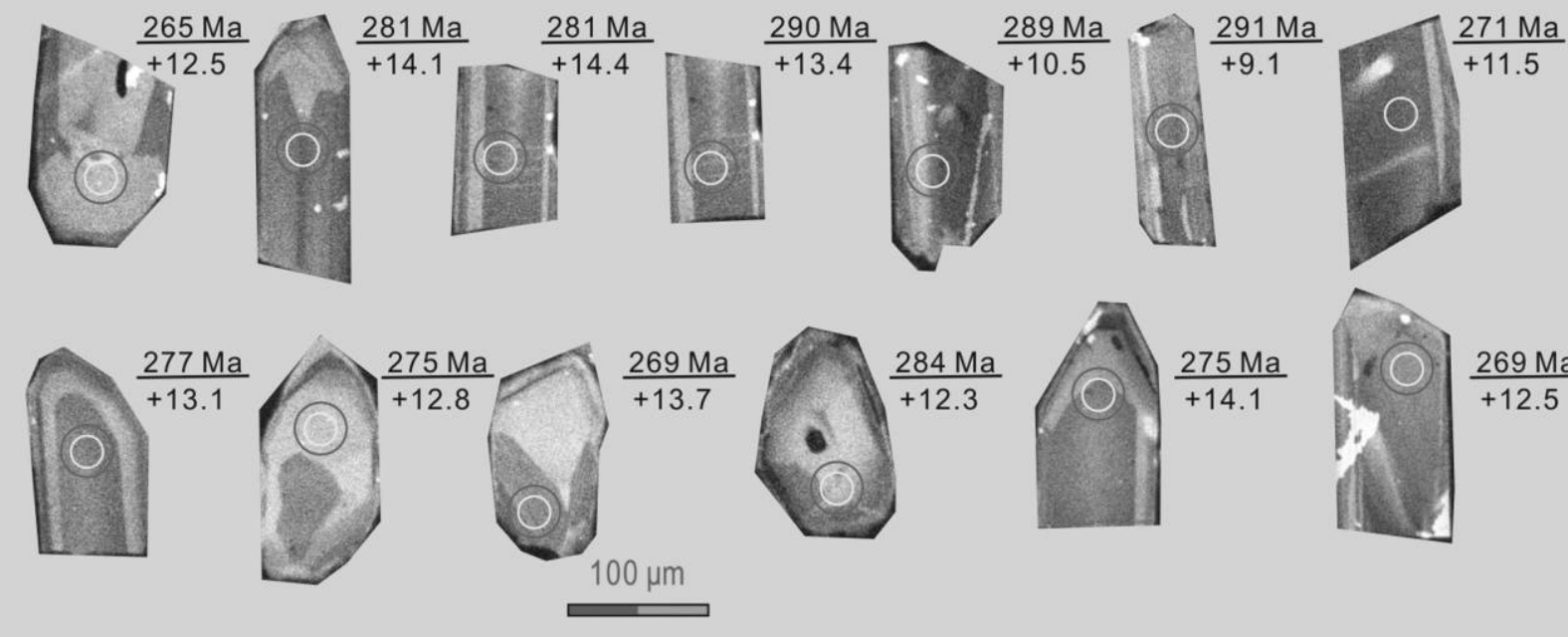

$\underline{269 \mathrm{Ma}}$ $+12.5$

Figure 4. Cathodoluminescene images of the analyzed zircon grains from the gabbronoritic and quartz dioritic dikes. Circles denote the analyzing locations, and numbers refer to U-Pb ages and $\varepsilon_{\mathrm{Hf}}(t)$ values. A color version of this figure is available online.

nese Academy of Sciences. Calibration lines used in quantification were produced by bivariate regression of data from 36 reference materials encompassing a wide range of silicate compositions (Li et al. 2006), and analytical uncertainties are $1 \%-5 \%$. The trace elements-including rare earth elements (REEs), high field strength elements (HFSEs), and large ion lithophile elements (LILEs) - were determined with a Perkin-Elmer Sciex ELAN 6000 ICP-MS, using nebulized sample solutions also at the Guangzhou Institute of Geochemistry. Analytical procedures are similar to those described by Liu et al. (1996) and Li (1997). Approximately 50-mg sample powders were dissolved in high-pressure Teflon bombs, using an $\mathrm{HF}+\mathrm{HNO}_{3}$ mixture. An internal standard solution containing the single element $\mathrm{Rh}$ was used to monitor signal drift during counting. A set of international and Chinese national rock standards - including BHVO-2, MRG-1, SY-4, G-2, and GSP-2 and GSR-1, GSR-2, GSR-3, and GSD-12-were used for calibrating ele- ment concentrations of unknowns. Analytical errors are generally $<15 \%$. The major and trace element results are presented in table S3.

Sr-Nd Isotope Analyses. Samples for $\mathrm{Sr}$ and $\mathrm{Nd}$ isotopic analysis were decomposed in a mixture of $\mathrm{HF}-\mathrm{HClO}_{4}$, and $\mathrm{Sr}$ and $\mathrm{Nd}$ were separated using a two-step ion exchange procedure. The ${ }^{87} \mathrm{Sr} /{ }^{86} \mathrm{Sr}$ and ${ }^{143} \mathrm{Nd} /{ }^{144} \mathrm{Nd}$ ratios were measured on a Micromass IsoProbe MC-ICP-MS at the Guangzhou Institute of Geochemistry, following the procedures described by Wei et al. (2002) and Liang et al. (2003). ${ }^{83} \mathrm{Kr},{ }^{84} \mathrm{Sr}$, ${ }^{85} \mathrm{Rb},{ }^{86} \mathrm{Sr},{ }^{87}(\mathrm{Rb}+\mathrm{Sr})$, and ${ }^{88} \mathrm{Sr}$ were simultaneously measured to monitor the interference of ${ }^{84} \mathrm{Kr}$, ${ }^{86} \mathrm{Kr}$, and ${ }^{87} \mathrm{Rb}$ on $\mathrm{Sr}$ isotopes. $\mathrm{Kr}$ interference comes predominantly from Ar gas and is generally at a very low level $(0.015 \%)$ and can be effectively eliminated after blank correction. Interference of ${ }^{87} \mathrm{Rb}$ can be estimated using ${ }^{85} \mathrm{Rb} /{ }^{87} \mathrm{Rb}=2.59265$ and a mass fractionation factor calculated on the basis of measured ${ }^{86} \mathrm{Sr} /{ }^{88} \mathrm{Sr}$ ratios and ${ }^{86} \mathrm{Sr} /{ }^{88} \mathrm{Sr}=0.1194 . \mathrm{NBS} 987$ 

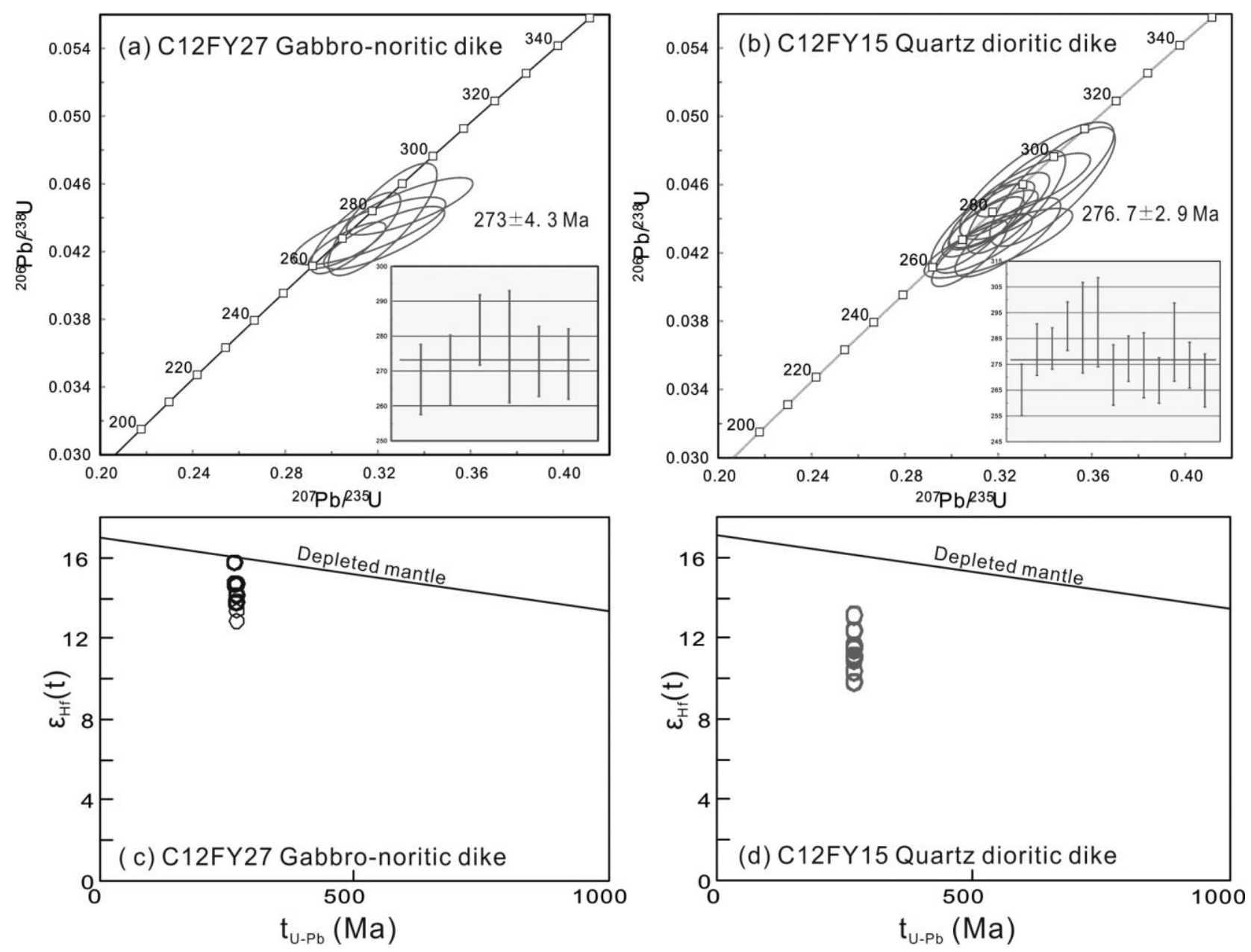

Figure 5. Laser ablation inductively coupled plasma mass spectrometry U-Pb zircon concordia diagrams and Hf isotopes for the gabbronoritic dikes and the quartz dioritic dikes. A color version of this figure is available online.

was used as the standard to monitor the instrumental performance for $\mathrm{Sr}$ isotope analyses, and multiple analyses of NBS987 yielded an average ${ }^{87} \mathrm{Sr} /{ }^{86} \mathrm{Sr}$ ratio of $0.710247 \pm 17(2 \sigma)$. Repeated analyses for the Shin Estu JNdi-1 standard during the course of this study yielded an average ${ }^{143} \mathrm{Nd} /{ }^{144} \mathrm{Nd}$ ratio of $0.512120 \pm$ $8(2 \sigma)$. Accordingly, the ${ }^{143} \mathrm{Nd} /{ }^{144} \mathrm{Nd}$ ratios reported in this study were adjusted relative to the Shin Estu JNdi-1 reference value of 0.512115 (Tanaka et al. 2000), corresponding to the La Jolla standard value of 0.511860 . The ${ }^{87} \mathrm{Rb} /{ }^{86} \mathrm{Sr}$ and ${ }^{147} \mathrm{Sm} /{ }^{144} \mathrm{Nd}$ ratios were calculated from the $\mathrm{Rb}-\mathrm{Sr}$ and $\mathrm{Sm}-\mathrm{Nd}$ concentrations determined by trace element analysis. The $\mathrm{Sr}$ and $\mathrm{Nd}$ isotopic compositions are listed in tables S4 and S5.

\section{Analytical Results}

Zircon U-Pb Age and HfIsotopes. Zircon grains from the gabbronorite are generally colorless and transparent and are characterized by euhedral prismatic shapes, concentric oscillatory zoning (fig. 4a), and high $\mathrm{Th} / \mathrm{U}$ ratios $(0.41-1.16)$, indicating an igneous origin. Six analyses define a coherent age population with a weighted mean ${ }^{206} \mathrm{~Pb} /{ }^{238} \mathrm{U}$ age of $273.2 \pm$ 4.3 Ma (fig. 5a), which is considered to record timing of emplacement for the gabbronorite. The calculated $\varepsilon_{\mathrm{Hf}}(t)$ values range from +13.2 to +16.7 (fig. $5 c$ ), and $T_{\mathrm{DM}}$ model ages are $318-387 \mathrm{Ma}$.

Zircon grains separated from the quartz diorite are prismatic and euhedral (fig. $4 b$ ), with high Th/U ratios (0.62-1.50), suggesting that they are also igneous in origin. Thirteen analyses yielded a coherent age population with a weighted mean ${ }^{206} \mathrm{~Pb} /{ }^{238} \mathrm{U}$ age of $276.7 \pm 2.9 \mathrm{Ma}$ (fig. $5 b$ ), which is taken as the intrusive age of the quartz diorite. The $\varepsilon_{\mathrm{Hf}}(t)$ values calculated at $277 \mathrm{Ma}$ are between +9.1 and +14.4 (fig. $5 d$ ), with $T_{\mathrm{DM}}$ model ages of 342-546 Ma.

Geochemical Characteristics. The gabbronorites are characterized by high $\mathrm{TiO}_{2}(1.92-2.48 \mathrm{wt} \%)$ and show a narrow range of $\mathrm{SiO}_{2}(47.1-51.3 \mathrm{wt} \%$; figs. $6 a, 7)$. 

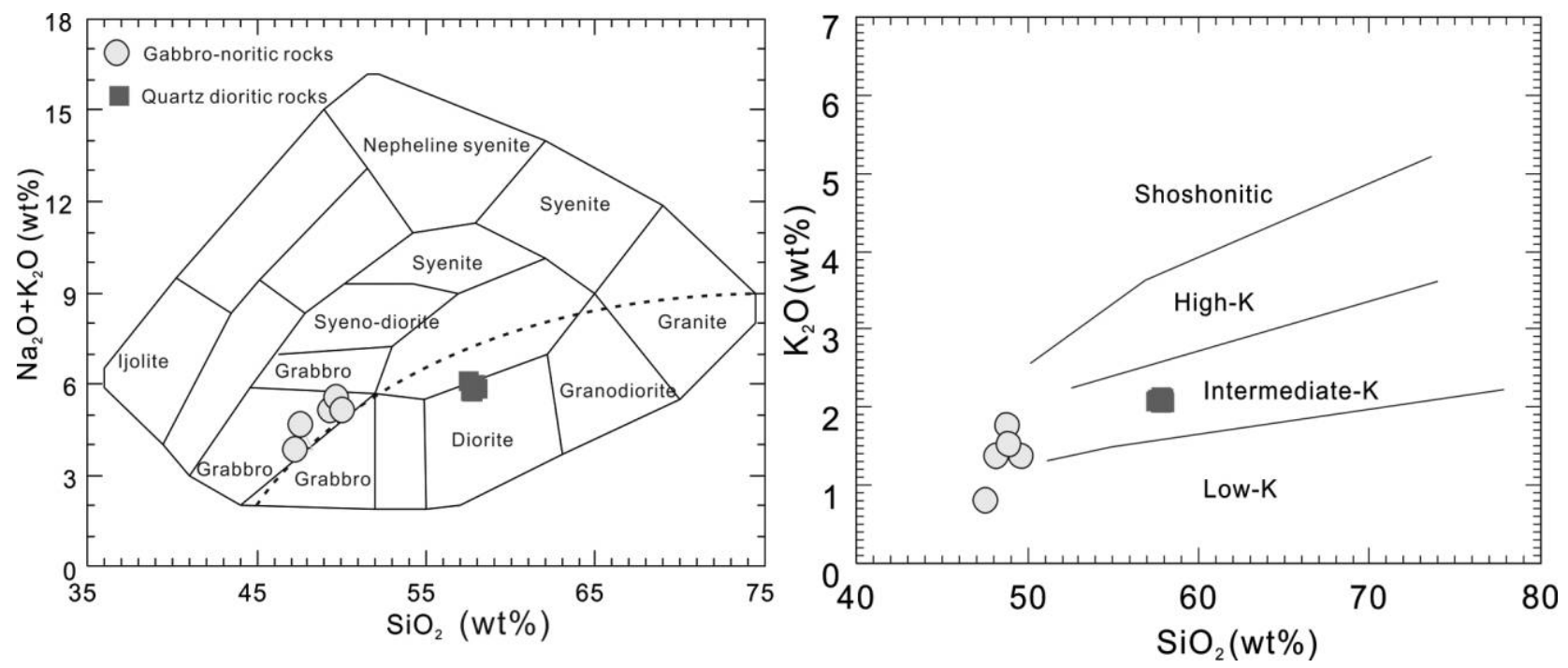

Figure 6. $\mathrm{Na}_{2} \mathrm{O}+\mathrm{K}_{2} \mathrm{O}$ versus $\mathrm{SiO}_{2}$ diagram (left; Cox et al. 1980) and $\mathrm{K}_{2} \mathrm{O}$ versus $\mathrm{SiO}_{2}$ plot (right) for the gabbronoritic and quartz dioritic dikes in the Fuyun region, Chinese Altai. A color version of this figure is available online.

Their $\mathrm{MgO}$ contents vary from 5.33 to $8.46 \mathrm{wt} \%$ $(\mathrm{Mg} \#=52.3-62.8)$. They are alkali rich $\left(\mathrm{K}_{2} \mathrm{O}+\right.$ $\mathrm{Na}_{2} \mathrm{O}=3.55-5.12 \mathrm{wt} \% ; \mathrm{K}_{2} \mathrm{O} \geq 0.74 \mathrm{wt} \%$ ) and mainly plot in the moderate-high $\mathrm{K}$ fields (fig. 6b). In Harker diagrams (fig. 7), $\mathrm{TiO}_{2}, \mathrm{Al}_{2} \mathrm{O}_{3}, \mathrm{Fe}_{2} \mathrm{O}_{3}^{\mathrm{T}}$, and $\mathrm{MgO}$ decrease with increasing $\mathrm{SiO}_{2}$, while $\mathrm{K}_{2} \mathrm{O}$ and $\mathrm{Na}_{2} \mathrm{O}$ exhibit positive correlations with $\mathrm{SiO}_{2}$ (fig. 7). The REE patterns show coherent enrichments of LREE $\left((\mathrm{La} / \mathrm{Yb})_{\mathrm{N}}=3.77-4.52\right)$ and flat heavy rare earth element (HREE) patterns $\left((\mathrm{Gd} / \mathrm{Yb})_{\mathrm{N}}=1.61-1.76\right)$, with weak negative $\mathrm{Eu}$ anomalies $\left(\mathrm{Eu}^{*} / \mathrm{Eu}=0.82-0.94\right.$; fig. $8 a$ ). In the primitive mantle-normalized multielement diagram, all gabbronorite samples show similar trends of significant enrichments in LILEs relative to HFSEs (fig. $8 b$ ).

The quartz diorites have relatively higher $\mathrm{SiO}_{2}$ contents (57.3-58.3 wt\%) and lower $\mathrm{TiO}_{2}(1.38-1.43$ $\mathrm{wt} \%)$ than those of the gabbronorites (figs. $6 a, 7)$. They display lower $\mathrm{MgO}$ contents (3.03-3.13 wt\%) and $\mathrm{Mg \#}$ of 48.5-49.3 relative to the gabbronorites. All samples plot in the medium-high K fields (fig. 6b), with high $\mathrm{K}_{2} \mathrm{O}$ contents $(\geq 1.89 \mathrm{wt} \%)$. In Harker diagrams, no linear variation is shown between major oxides and $\mathrm{SiO}_{2}$ (fig. 7). The quartz diorites have lower $\mathrm{Cr}$ and $\mathrm{Ni}$ but higher total REE contents than those of the gabbronorites (fig. 8c) and show moderately negative $\mathrm{Eu}$ anomalies $\left(\mathrm{Eu}^{*} / \mathrm{Eu}=0.63-0.69\right)$, slightly enriched LREE $\left((\mathrm{La} / \mathrm{Nd})_{\mathrm{N}}=9.42-10.62\right)$, and relatively flat HREE $\left((\mathrm{Gd} / \mathrm{Yb})_{\mathrm{N}}=1.87-2.04\right)$. Similarly, in the primitive mantle-normalized trace element diagram, the quartz diorites have coherent patterns, with enrichment in LILEs (e.g., $\mathrm{U}$ and $\mathrm{Pb}$ ), negative HFSEs (e.g., $\mathrm{Nb}, \mathrm{Ta}, \mathrm{Zr}$, and $\mathrm{Hf}$ ) and $\mathrm{Sr}$, and Eu anomalies (fig. 8d).
Sr-Nd Isotopic Compositions. The gabbronorite samples have $\varepsilon_{\mathrm{Nd}}(t)$ values of +4.9 to +6.1 and initial ratios of ${ }^{87} \mathrm{Sr} /{ }^{86} \mathrm{Sr}_{(i)}=0.7036-0.7038$ that resemble those of the Permian hornblende gabbros $\left(\varepsilon_{\mathrm{Nd}}(t)=\right.$ +4.8 to $\left.+6.0,{ }^{87} \mathrm{Sr} /{ }^{86} \mathrm{Sr}_{(\mathrm{i})}=0.7034-0.7035\right)$ and the Triassic continental basalts $\left(\varepsilon_{\mathrm{Nd}}(t)=+4.3\right.$ to +5.2 , ${ }^{87} \mathrm{Sr} /{ }^{86} \mathrm{Sr}_{(i)}=0.7047-0.7052$; Yuan et al. 2011; Wan et al. 2013) in the region but are lower than those of the Permian mafic intrusions in the Kalatongke area $\left(\varepsilon_{\mathrm{Nd}}(t)=+6.3\right.$ to $+8.2,{ }^{87} \mathrm{Sr} /{ }^{86} \mathrm{Sr}_{(\mathrm{i})}=0.7038-0.7050$; Zhang et al. 2009). The quartz diorites exhibit lower $\varepsilon_{\mathrm{Nd}}(t)$ values $(\sim+2.5)$ and higher initial ratios of ${ }^{87} \mathrm{Sr} /$ ${ }^{86} \mathrm{Sr}_{(i)}(0.7048)$ than those of the gabbronorite samples (fig. 9) but are close to those of the Devonian Keketuohai mafic-ultramafic complex $\left(\varepsilon_{\mathrm{Nd}}(t)=0\right.$ to +2.7 , ${ }^{87} \mathrm{Sr} /{ }^{86} \mathrm{Sr}_{(i)}=0.7046-0.7062$; Cai et al. 2012b).

\section{Discussion}

Petrogenesis and Magma Source of the Gabbronorites. Since pyroxenes are partly replaced by chlorite and plagioclases show features of sericitization, it is necessary to evaluate the element mobility of the gabbronorites before discussing their petrogenesis and source nature. We note that the gabbronoritic rocks have a relatively low loss on ignition index (LOI $=$ $0.80-1.74 \mathrm{wt} \%)$, and their trace elements display coherent patterns in the primitive mantle-normalized spider diagram (fig. 8), which are considered as evidence of only a weak influence on chemical compositions by the mineral alteration. Accordingly, the geochemical data should, to a great extent, faithfully record the original compositions. The gabbronorites have low $\mathrm{SiO}_{2}(47.1-51.3 \mathrm{wt} \%)$ and high $\mathrm{MgO}$ (5.33- 

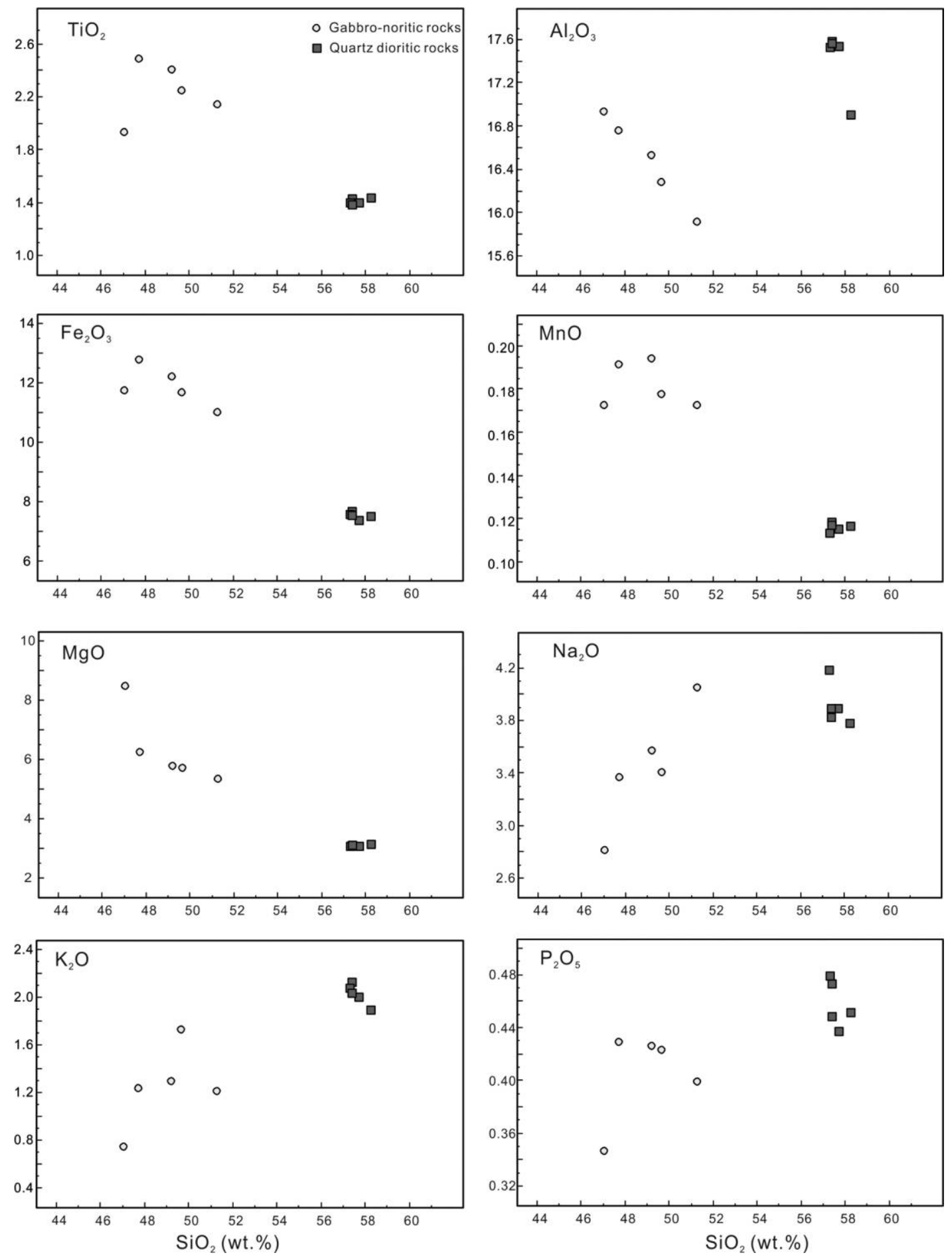

Figure 7. Variation diagrams for major oxides versus $\mathrm{SiO}_{2}$ for the gabbronoritic and quartz dioritic dikes. Symbols as in figure 6. A color version of this figure is available online.

$8.46 \mathrm{wt} \%)$ contents as well as high zircon $\varepsilon_{\mathrm{Hf}}(t)(+13.2$ to +16.7$)$ and whole-rock $\varepsilon_{\mathrm{Nd}}(t)(+4.9$ to +6.1$)$ values, suggesting parental magma derivations from a depleted mantle source. Compared with those of the primitive basalts $(\mathrm{Mg} \#=63-73, \mathrm{Ni}=84.6-442 \mathrm{ppm}, \mathrm{Cr}=$
266-975 ppm; Green 1975; Frey et al. 1978; Hess 1992; Kelemen et al. 2003), variations of Mg\# (52.3-62.8) and lower $\mathrm{Ni}(80.6-192 \mathrm{ppm})$ and $\mathrm{Cr}(71.2-95.7 \mathrm{ppm})$ contents may be due to fractional crystallization of ferromagnesian minerals (e.g., olivine, pyroxene, and/ 

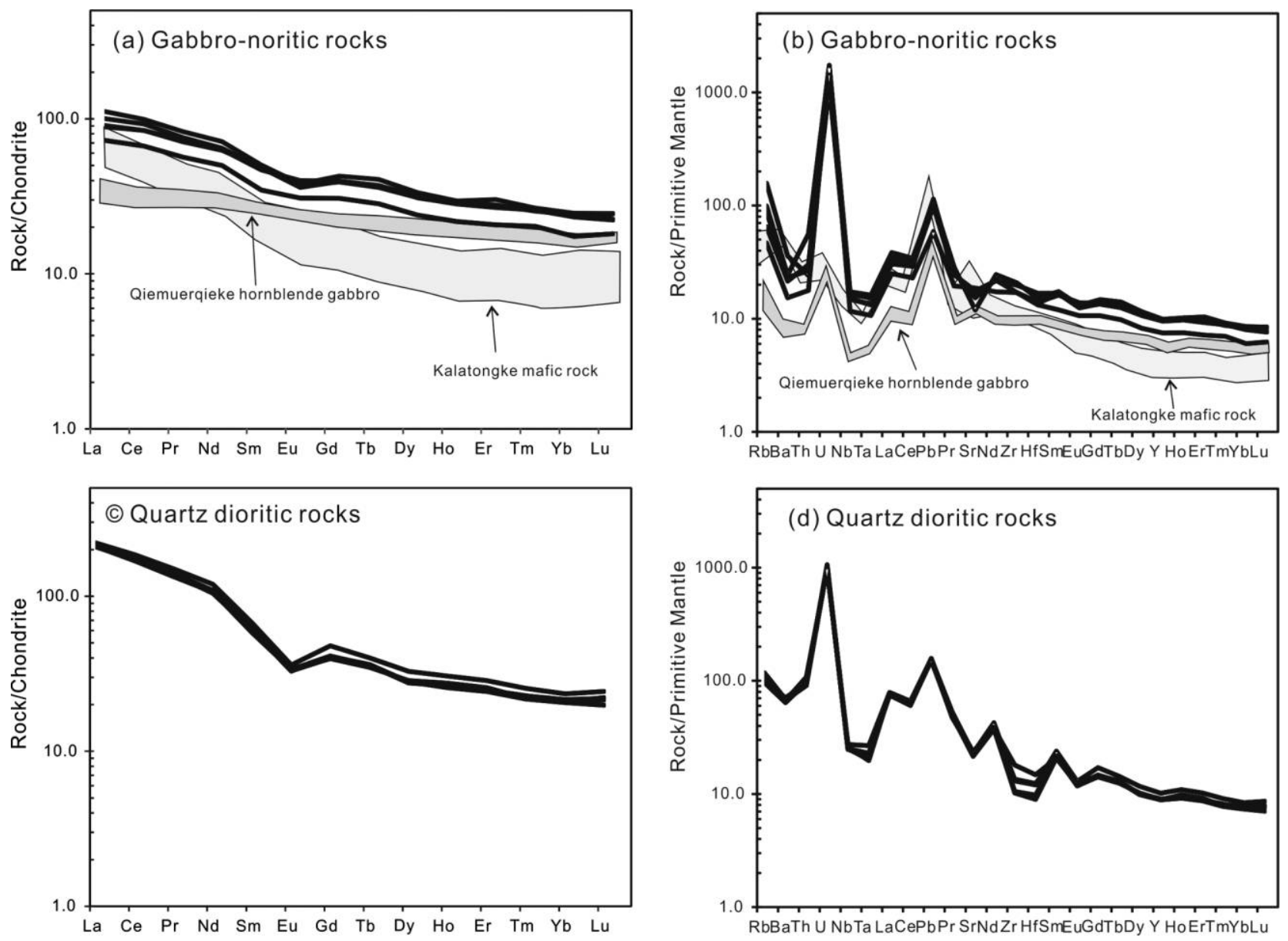

Figure 8. Chondrite-normalized rare earth element patterns and primitive mantle-normalized trace element spider diagram for the gabbronoritic and quartz dioritic dikes. Normalizing values are from Sun and McDonough (1989). Symbols as in figure 6. A color version of this figure is available online.

or Cr spinel) and/or crustal contamination. However, the limited variation of $\mathrm{SiO}_{2}(47.1-51.3 \mathrm{wt} \%)$ denotes a weak influence of fractional crystallization during magma evolution.

Crustal contamination may occur in the mantle source, along the route of magma ascent, and/or during final emplacement. Because the bulk crust has higher $(\mathrm{Th} / \mathrm{Yb})_{\mathrm{N}}$ and lower $(\mathrm{Ta} / \mathrm{Th})_{\mathrm{N}}$ than those of mantle-derived magma, $(\mathrm{Th} / \mathrm{Yb})_{\mathrm{N}}$ and $(\mathrm{Ta} / \mathrm{Th})_{\mathrm{N}}$ are generally applied as valid parameters to estimate the degree of crustal contamination (fig. 10a). Compared with normal mid-ocean ridge basalt $(\mathrm{N}-$ MORB) and enriched MORB (E-MORB), the gabbronorites are characterized by strikingly higher $(\mathrm{Th} / \mathrm{Yb})_{\mathrm{N}}$ and lower $(\mathrm{Ta} / \mathrm{Th})_{\mathrm{N}}$ ratios. If the average composition of the Devonian low-grade metamorphic sediments is taken as the potential crustal contaminant, our samples do not well match the modeling curves defined by either an N-MORB or E-MORB single mantle source. Alternatively, if a mixed mantle source is chosen for the magma source, the result suggests that the extent of crustal contamination of the gabbronorite rocks may be between $4 \%$ and $12 \%$ (fig. 10a). Nevertheless, such a low degree of crustal contamination is consistent with the strikingly positive zircon $\varepsilon_{\mathrm{Hf}}(t)(+13.2$ to +16.7$)$ and whole-rock $\varepsilon_{\mathrm{Nd}}(t)(+4.9$ to +6.1$)$ values and the coherent REE and HFSE contents of these rocks. Because $\mathrm{Yb}\left(D_{\text {spinel } / \mathrm{melt}}=0.0045\right)$ and $\mathrm{Sm}\left(D_{\text {spinel } / \mathrm{melt}}=\right.$ 0.0006) have similar partition coefficients, partial melting of spinel lherzolite generally gives constant $\mathrm{Sm} / \mathrm{Yb}$ ratios (Aldanmaz et al. 2000; Green 2006). In contrast, garnet has significant uptakes of $\mathrm{Yb}$ $\left(D_{\text {garnet } / \text { melt }}=6.6\right)$ over $\operatorname{Sm}\left(D_{\text {garnet } / \text { melt }}=0.25\right)$; thus, partial melting of garnet peridotites results in elevated $\mathrm{Sm} / \mathrm{Yb}$ ratios (Johnson 1994). The gabbronorites have $\mathrm{Sm} / \mathrm{Yb}$ ratios (1.75-1.89) and Sm contents (5.32-7.47 ppm) similar to partial melts derived from a mantle source of dominant spinel lherzolite (fig. 10b). In contrast, the Qiemuerqieke hornblende-bearing 


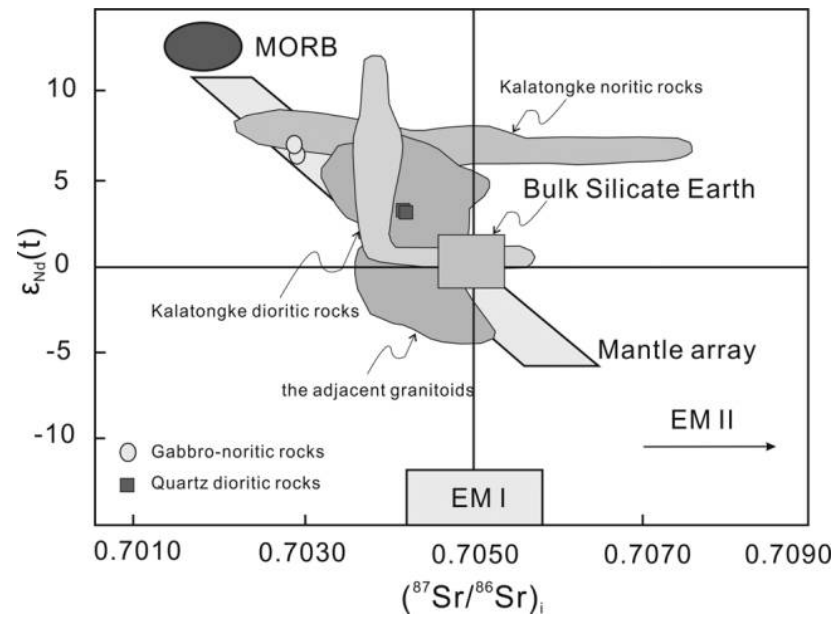

Figure 9. Initial ${ }^{87} \mathrm{Sr} /{ }^{86} \mathrm{Sr}$ versus ${ }^{143} \mathrm{Nd} /{ }^{144} \mathrm{Nd}$ diagram for the gabbronoritic and quartz dioritic dikes in the Fuyun region. MORB, mid-ocean ridge basalt. A color version of this figure is available online.

gabbro in the Chinese Altai may be sourced from a relatively shallower mantle source that was also dominated by spinel lherzolites, as suggested by their lowest $\mathrm{Sm} / \mathrm{Yb}$ ratios (fig. $10 b$ ).

Petrogenesis and Magma Source of the Quartz Diorites. Although the quartz diorites were emplaced at $277 \mathrm{Ma}$, coeval with the gabbronorites, contrasting isotope compositions and the lack of transitional components do not support the possibility that the quartz diorites are derivatives of the gabbronorites by fractional crystallization. The quartz diorites have intermediate $\mathrm{SiO}_{2}(57.3-58.3 \mathrm{wt} \%)$ contents and moderately positive $\varepsilon_{\mathrm{Nd}}(t)(\sim+2.5)$ and zircon $\varepsilon_{\mathrm{Hf}}(t)$ $(+9.1$ to +14.4$)$ values, suggesting that their precursor magmas were sourced from a relatively less depleted mantle source or juvenile mafic crust. The restricted $\mathrm{SiO}_{2}(57.3-58.3 \mathrm{wt} \%)$ and the limited variations of $\mathrm{MgO}$ contents (3.03-3.13 wt \%) indicate that the parental magma may not have been influenced by fractional crystallization and/or crustal contamination. Eichelberger (1978) advocated that andesitic volcanic rock is a mixture of melts from the upper mantle and lower crust. Although the quartz diorites have chemical compositions resembling the andesitic volcanic rocks, there is no solid evidence from petrographic investigations to support magma mixing. In addition, the parental magma is unlikely to be derived from partial melting of oceanic crust, which generally yields adakitic melts with high $\mathrm{Sr} / \mathrm{Y}$ ratios (e.g., Defant and Drummond 1990). Therefore, we ascribe the parental magma of the quartz diorites to partial melting of juvenile mafic lower crust, because a thick, up to 46-km mafic-intermediate igneous rock layer exists at the depths of the middle to lower crust (Wang et al. 2003).

Experimental (e.g., Helz 1976; Beard and Lofgren 1991; Rapp et al. 1991; Rushmer 1991; Wolf and Wyllie 1994; Rapp and Watson 1995) and theoretical (e.g., Roberts and Clemens 1993) studies demonstrate that dehydration melting of basaltic rocks within the lower crust with high heat flow can
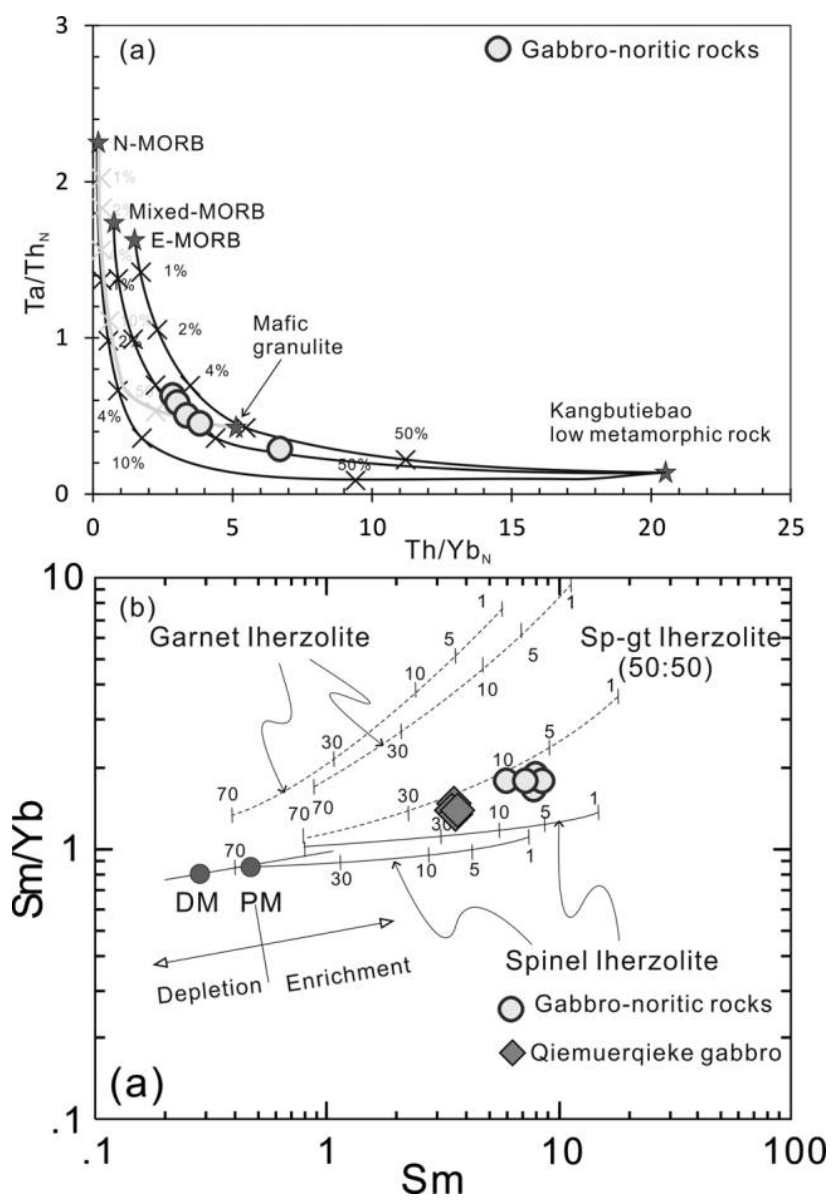

Figure 10. $a,(\mathrm{Th} / \mathrm{Yb})_{\mathrm{N}}$ versus $(\mathrm{Ta} / \mathrm{Yb})_{\mathrm{N}}$ diagram for the gabbronoritic and quartz dioritic rocks. The curve represents the simple mixing modeling results. Mixing mantle source between normal mid-ocean ridge basalt $(\mathrm{N}$ MORB) and enriched MORB (E-MORB) is considered to be the presumed parental magma, and the Kangbutiebao low metamorphic rock (Long et al. 2007) is used to be a potential crustal contaminant. $b$, Plots of $\mathrm{Sm} / \mathrm{Yb}$ versus $\mathrm{Sm}$ for the gabbronoritic rocks in the Fuyun region. Mantle array defined by depleted MORB mantle (DM; McKenzie and O'Nions 1991) and primitive mantle (PM; Sun and McDonough 1989). Melting curves for spinel lherzolite $\left(\mathrm{Ol}_{53}+\mathrm{Opx}_{27}+\mathrm{Cpx}_{17}+\mathrm{Sp}_{11}\right)$ and garnet peridotite $\left(\mathrm{Ol}_{60}+\right.$ $\mathrm{Opx}_{20}+\mathrm{Cpx}_{10}+\mathrm{Gt}_{10}$ ) with both DM and PM compositions are after Aldanmaz et al. (2000). Numbers along lines represent the degree of the partial melting. A color version of this figure is available online. 

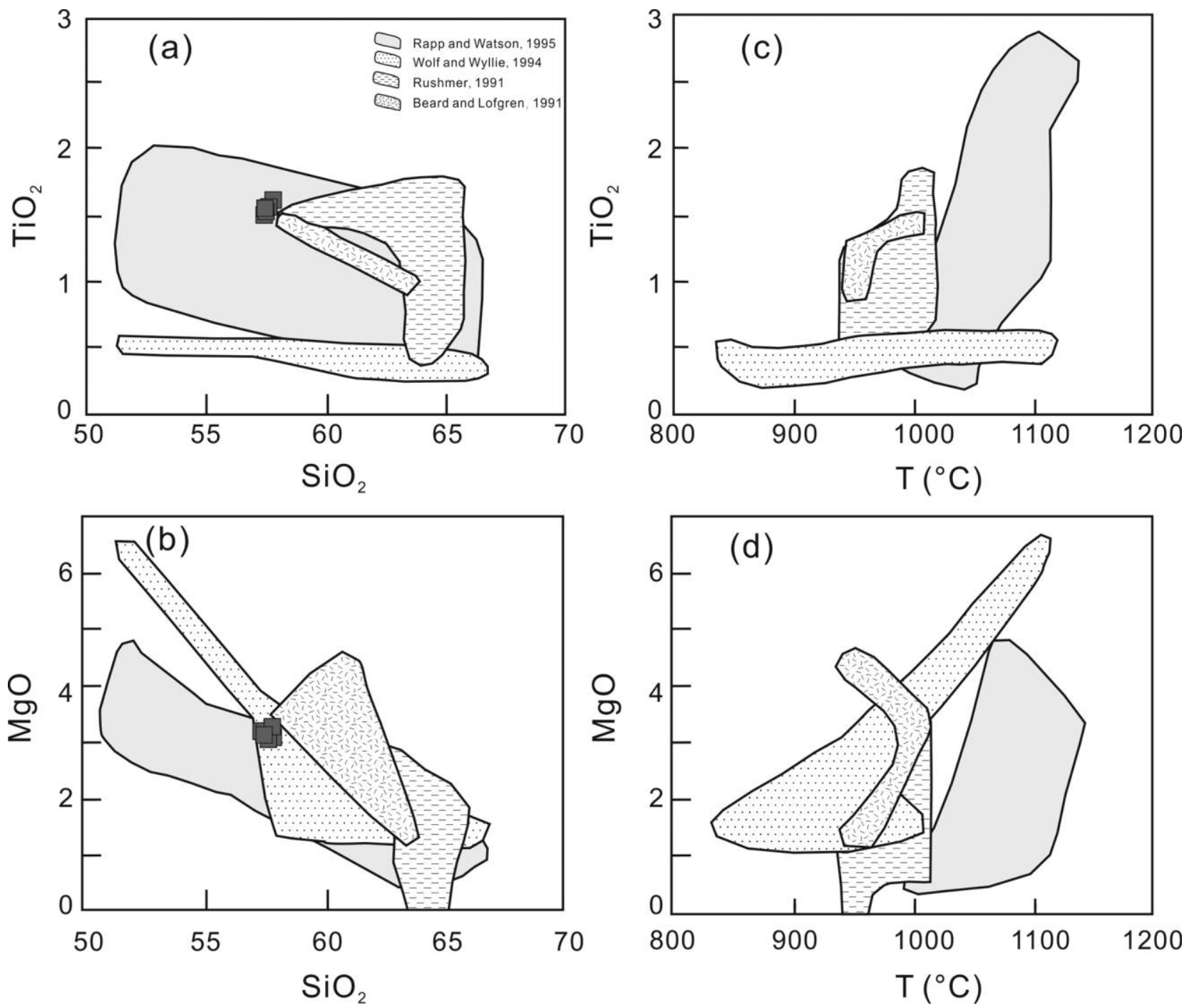

Figure 11. Plots of $\mathrm{TiO}_{2}$ and $\mathrm{MgO}$ versus $\mathrm{SiO}_{2}(a, b)$ and of $\mathrm{TiO}_{2}$ and $\mathrm{MgO}$ versus temperature $(c, d)$ for the Fuyun quartz diorites and experimental investigations. Note that the composition of the quartz diorites is likely reproduced by high-temperature melting of a source similar to the alkali-enriched basaltic rocks of Rapp and Watson (1995).

produce significant volumes of mafic-intermediate melts. Specifically, dehydration melting of amphibolite can give rise to $10 \%-60 \%$ quartz diorite in tonalite melts at temperatures of $900^{\circ}-1100^{\circ} \mathrm{C}$, whereas $\mathrm{H}_{2} \mathrm{O}$-saturated partial melting can produce similar amounts of granitic melts at lower temperatures, between $850^{\circ}$ and $900^{\circ} \mathrm{C}$ (e.g., Rapp et al. 1991; Wolf and Wyllie 1994; Rapp and Watson 1995). The quartz diorites of this study have chemical compositions overlapping those of partial melts derived from metabasaltic rocks. For instance, they possess medium $\mathrm{SiO}_{2}$, high $\mathrm{Al}_{2} \mathrm{O}_{3}$, moderate $\mathrm{Na}_{2} \mathrm{O} / \mathrm{K}_{2} \mathrm{O}$, high LREE, and moderate HREE concentrations (figs. 6-8). Experimental studies show that garnet generally occurs as a major residual mineral of crustal partial melting at greater depths (>10 kbar; e.g., Rapp et al. 1991;
Wolf and Wyllie 1994; Rapp and Watson 1995), which retains the majority of $Y$ and HREE, resulting in significant deficiencies of such elements in relevant partial melts. As for the quartz diorites of this study, they have high $\mathrm{Y}(>39.8 \mathrm{ppm})$ and HREE (Yb >3.64 ppm) concentrations and low $\mathrm{Sr} / \mathrm{Y}$ ratios $(<12)$, suggesting that dehydration melting should take place at shallow depths at least above the garnet stability field < 10 kbar; e.g., Patiño Douce 1996; Singh and Johannes 1996). The negative Sr and Eu anomalies may be due to plagioclase residue in the magma source, whereas the relatively high $\mathrm{TiO}_{2}$ contents and insignificant MREE depletion suggest that amphibole was not a residual phase (e.g., Petford and Atherton 1996). Collectively, the chemical compositions of the quartz diorites are consistent with the intermediate liquids 


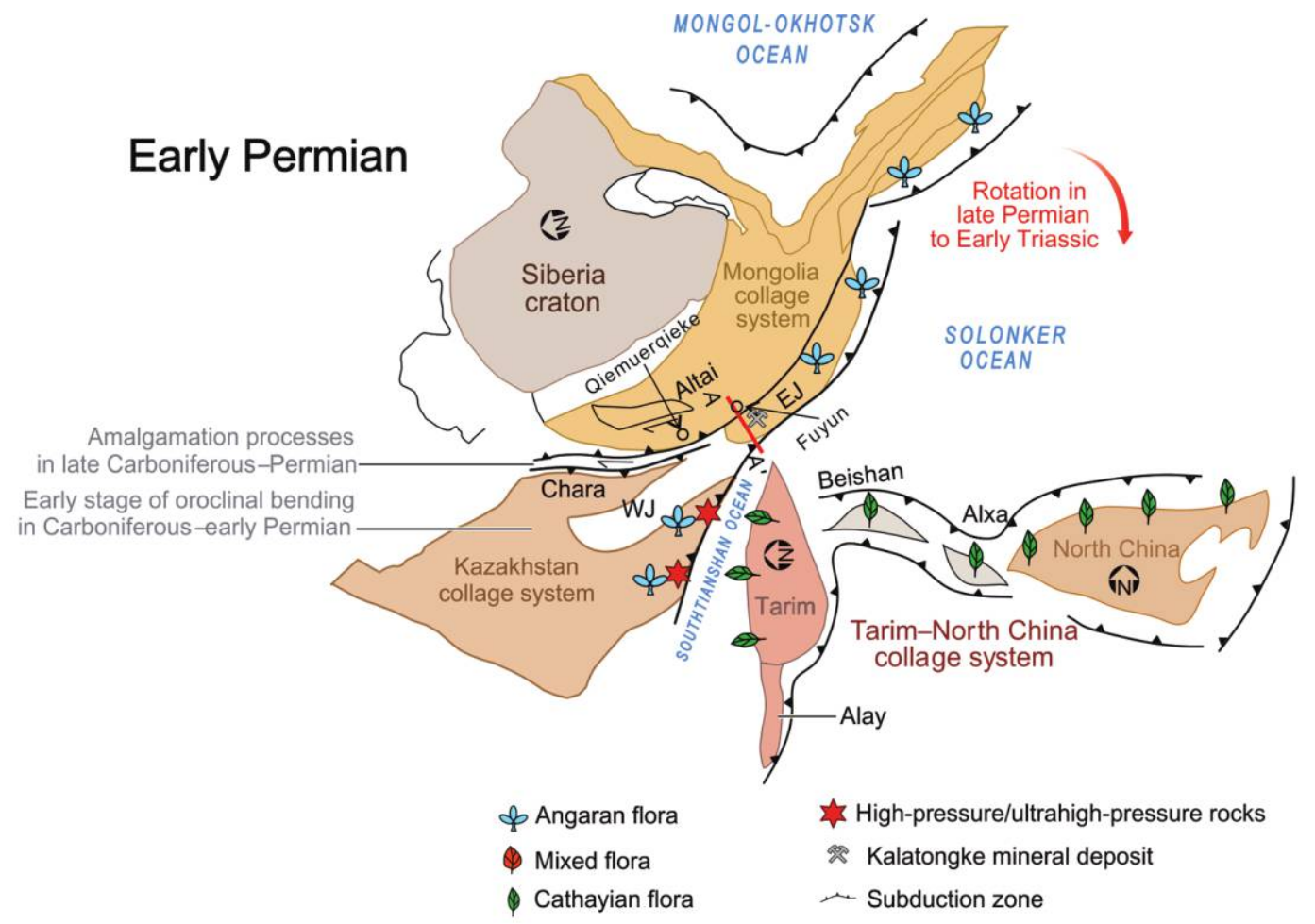

Southeast Chinese Altai

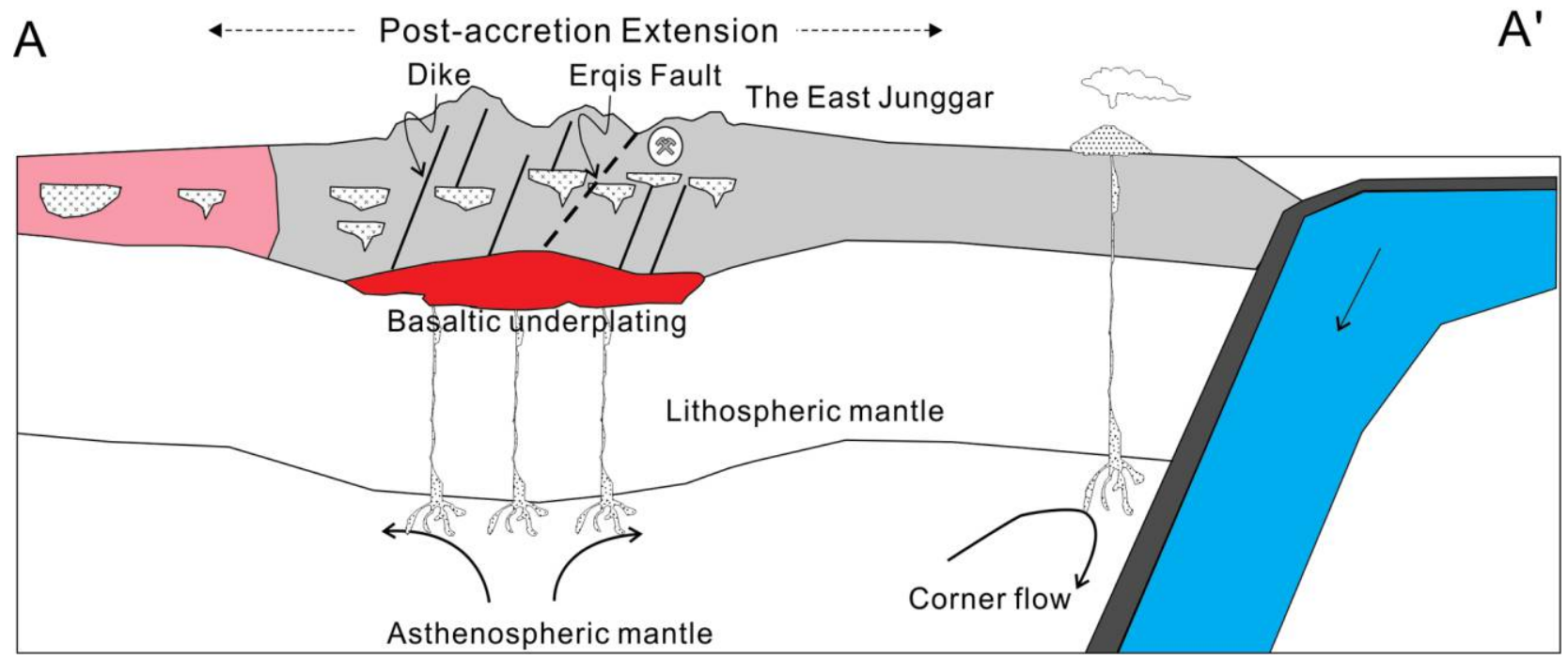

Figure 12. Early Permian paleogeographic reconstructions showing simplified plate boundaries and labels of some major features of the Central Asian Orogenic Belt and the postaccretion extensional scenario are illustrated for the southeast Chinese Altai (modified after Xiao et al. 2015).

(quartz dioritic, dioritic), produced by $\sim 40 \%$ partial melting of basaltic rocks at $T=1050^{\circ}-1100^{\circ} \mathrm{C}$ and $P=8$ kbar with granulite (plagioclase + clinopyroxene \pm orthopyroxene \pm olivine) as a residue (Wolf and Wyllie 1994; Rapp and Watson 1995). Moreover, the quartz diorites are characterized by high $\mathrm{K}_{2} \mathrm{O}$ $(>1.89 \mathrm{wt} \%)$, similar to experimental melts produced by partial melting of alkali basaltic and high-Al basaltic sources (fig. 11) but different from those generated by low K-basaltic rocks (Wolf and Wyllie 1994; Rapp and Watson 1995). On the other hand, the high $\mathrm{MgO}$ contents ( $>3.03 \mathrm{wt} \%$ ) of the quartz diorites imply that high-Al basaltic sources may be unlikely. In summary, the magma source of the quartz diorites 
was likely dominated by alkali-enriched basaltic rock, which may be melted at relatively shallow depths of the lower crust.

Partial melting of the lower crust is generally related to high heat regime. In the south Chinese Altai, 260-280 Ma high-temperature granulites have been reported (Chen et al. 2006b; Tong et al. 2014). PT estimates suggest that metapelitic granulite might have undergone peak metamorphic conditions of $P=\sim 8$ kbar and $T=\sim 960^{\circ} \mathrm{C}$ (Tong et al. 2014) and that basic granulite had a peak metamorphic temperature exceeding $950^{\circ} \mathrm{C}$ (Li et al. 2010). Moreover, the basic granulites consist mainly of plagioclase, clinopyroxene, and orthopyroxene as well as minor amphibole and biotite (Li et al. 2004), resembling the residue mineral assemblage after partial melting of amphibolites at $1050^{\circ}-1100^{\circ} \mathrm{C}$ and $8 \mathrm{kbar}$ (e.g., Wolf and Wyllie 1994; Rapp and Watson 1995). These lines of evidence suggest a high geothermal gradient in the south Chinese Altai when the quartz diorites were generated.

Tectonic Scenario of the South Chinese Altai in the Permian. Recent studies have documented that the Chinese Altai is composed mainly of early Paleozoic sedimentary, volcanic, and granitic rocks, similar to a Japan-type island arc (Xiao et al. 2004, 2009, 2015). The intermediate-mafic dikes in our study crop out in the south Chinese Altai, which is dominated by an accreted Silurian-Early Devonian island arc (Sun et al. 2008; Cai et al. 2011c). Zhang et al. (2015) advocated that the island arc was accreted to the main body of the Chinese Altai in the Devonian and jointly underwent multiple shortening events before the crustal-scale sinistral strike-slip shearing along the Erqis fault zone at 290-240 Ma. We note that the South Chinese Altai, as a crucial component of the Mongolia collage system (Xiao et al. 2015), merged with several separate tectonic units involving the West Junggar, Junggar basin, and East Junggar. The temporal and spatial variations (fig. 12) imply that the amalgamation history of the region can be hardly reconciled by a simple tectonic scenario.

In the Fuyun region, where our intermediate-mafic dikes crop out (figs. 1, 2), the East Junggar arc was docked to the Mongolia collage system in the early Permian, and the active margin was changed into a back-arc or intraplate setting. A sequence of tectonic events may have been witnessed by diagnostic structural evidence and distinctive magmatism. The NW-extending intermediate-mafic dikes show an extensional state perpendicular to the strike of Altai orogen in the Permian. This extensional scenario facilitated emplacement of synchronous A-type granites in the region (Han et al. 1997; Briggs et al. 2007; Sun et al. 2009; Tong et al. 2012). In addition, Gao and
Zhou (2013) suggested that magma from an $\sim 308 \mathrm{Ma}$ dioritic suite was derived from the thickened crust during the amalgamation of the Chinese Altai with the East Junggar, and a noritic suite in the Kalatongke area subsequently formed from a mantle-derived high-Mg magma as a result of the upwelling of the asthenospheric mantle in a postaccretion environment. Li et al. (2012) related the formation of the Kalatongke intrusions to decompression melting in upwelling of the asthenosphere as a result of slab break-off during a transitional period from oceanic subduction to collision in the early Permian. We should emphasize that the Permian mafic-ultramafic rocks and A-type granites are mainly distributed along the Erqis suture zone, suggesting a relatively thin and weak lithosphere along the deep fault, which is most favorable for magma emplacement (Griffiths and Campbell 1991). For the southeast Chinese Altai (fig. 12), we outline a tectonic evolution that involves a sequence of tectonic scenarios from ocean subduction, terrane amalgamation, and subducting slab break-off to post-accretion extension, which took place in the late Carboniferous to Permian. Owing to amalgamation of the Chinese Altai with the East Junggar, the Mongolian collage system was considerably enlarged, and the active margin likely migrated southward (fig. 12).

\section{Conclusions}

1. The grabbronoritic and quartz dioritic dikes were emplaced at $276.7 \pm 2.9$ and $273.2 \pm 4.3 \mathrm{Ma}$, respectively, in the southern Chinese Altai. This igneous activity was broadly coeval with the Permian magmatism in the region.

2. Parental magmas of the grabbronorites might have originated from a depleted mantle source dominated by spinel lherzolite. The quartz diorites were likely derived from a juvenile basaltic crust, which may have been closely related to the intraplating and/ or underplating of hot mantle-derived magmas.

3. The Permian intermediate-mafic dikes formed in an extensional environment after the amalgamation of the southeast Chinese Altai with the East Junggar.

\section{A C K N O W LED G M EN T S}

This study was financially supported by the Major Basic Research Project of the Ministry of Science and Technology of China (grants 2014CB448000, 2014CB440801, and 2014CB440802), Xinjiang outstanding youth scientific grant (2013711003), Hong Kong Research Grant Council (HKU704712P and 704313P), and National Science Foundation of China 
(41273048). B.-M. Jahn acknowledges the support of the National Science Council (NSC) of Taiwan (Ministry of Science and Technology [MOST] Taiwan) through research projects NSC-100-2923-M-002010, NSC101-2116-M-002-003, NSC102-2116-M-002031, and MOST 104-2923-M-002-005. K. D. Cai appreciates the support of MOST 103-2811-M-002-108 for visiting National Taiwan University. This work is a contribution to the Talent Awards to K. D. Cai from the China Government under the 1000 Talent Plan and the Hundred Talent Program of the Xinjiang Government, and it is also a contribution to International Geoscience Programme 592. We are grateful to D. B. Rowley, B. Wang, and an anonymous reviewer for their critical reviews and comments that significantly improved the manuscript.

\section{REFEREN C E S C I T E D}

Aldanmaz, E.; Pearce, J. A.; Thirlwall, M. F.; and Mitchell, J. G. 2000. Petrogenetic evolution of late Cenozoic, postcollision volcanism in western Anatolia, Turkey. J. Volcanol. Geotherm. Res. 102:67-95.

Andersen, T. 2002. Correction of common lead in U$\mathrm{Pb}$ analyses that do not report ${ }^{204} \mathrm{~Pb}$. Chem. Geol. 192: 59-79.

Badarch, G.; Cunningham, W. D.; and Windley, B. F. 2002. A new terrane subdivision for Mongolia: implications for the Phanerozoic crustal growth of Central Asia. I. Asian Earth Sci. 21:87-110.

Beard, J. S., and Lofgren, G. E. 1991. Dehydration melting and water saturated melting of basaltic and andesitic greenstones and amphibolites at 1,3 and $6.9 \mathrm{kbar}$. I. Petrol. 32:365-402.

Bernard Edel, J.; Schulmanna, K.; Hanžl, P.; and Lexad, O. 2014. Palaeomagnetic and structural constraints on $90^{\circ}$ anticlockwise rotation in SW Mongolia during the Permo-Triassic: implications for Altaid oroclinal bending. Preliminary palaeomagnetic results. I. Asian Earth Sci. 94:157-171.

BGMRX (Bureau of Geology and Mineral Resources of Xinjiang Uygur Autonomous Region). 1993. Regional geology of Xinjiang uygur autonomous region. People's Republic of China, Ministry of Geology and Mineral Resources. Geological Memoirs 32. Beijing, Geological Publishing House (in Chinese).

Black, L. P.; Kamo, S. L.; Williams, I. S.; Mundil, R.; Davis, D. W.; Korsch, R. J.; and Foudoulis, C. 2003. The application of SHRIMP to Phanerozoic geochronology: a critical appraisal of four zircon standards. Chem. Geol. 200:171-188.

Blichert-Toft, J., and Albarede, F. 1997. The Lu-Hf geochemistry of the chondrites and the evolution of the mantle-crust system. Earth Planet. Sci. Lett. 148:243258.

Briggs, S. M.; Yin, A.; Manning, C. E.; Chen, Z. L.; Wang, X. F.; and Grove, M. 2007. Late Paleozoic tectonic history of the Ertix Fault in the Chinese Altai and its implications for the development of the Central Asian Orogenic System. Geol. Soc. Am. Bull. 119:944-960.

Cai, K. D.; Sun, M.; Xiao, W. J.; Buslov, M. M.; Yuan, C.; Zhao, G. C.; and Long, X. P. 2014a. Zircon U-Pb geochronology and $\mathrm{Hf}$ isotopic composition of granitiods in Russian Altai Mountain, Central Asian Orogenic Belt. Am. I. Sci. 314:580-612.
Cai, K. D.; Sun, M.; Xiao, W. J.; Yuan, C.; Zhao, G. C.; Long, X. P.; Tumurkhuu, D.; and Zhou, K. F. 2014b. Petrogenesis of late Paleozoic tholeiite, calc-akaline and adakitic rocks in the southwestern Mongolia: implications for intraoceanic arc evolution. Lithos 202/203:413-428.

Cai, K. D.; Sun, M.; Yuan, C.; Long, X. P.; and Xiao, W. J. 2011a. Geological framework and Paleozoic tectonic history of the Chinese Altai, NW China: a review. Russian Geol. Geophys. 52:1585-1599.

Cai, K. D.; Sun, M.; Yuan, C.; Zhao, G. C.; Xiao, W. J.; and Long, X. P. 2012a. Keketuohai mafic-ultramafic complex from the Chinese Altai, NW China: petrogenesis and geodynamic significance. Chem. Geol. 294/295:2641.

Cai, K. D.; Sun, M.; Yuan, C.; Zhao, G. C.; Xiao, W. J.; Long, X. P.; and Wu, F. Y. 2012b. Carboniferous mantlederived felsic intrusion in the Chinese Altai, NW China: implications for geodynamic change of the accretionary orogenic belt. Gondwana Res. 22:681-698.

. 2010. Geochronological and geochemical study of mafic dykes from the northwest Chinese Altai: implications for petrogenesis and tectonic evolution. Gondwana Res. 18:638-652.

-. 2011b. Geochronology, petrogenesis and tectonic significance of peraluminous granites from the Chinese Altai, NW China. Lithos 127:261-281.

. 2011c. Prolonged magmatism, juvenile nature and tectonic evolution of the Chinese Altai, NW China: evidence from zircon $\mathrm{U}-\mathrm{Pb}$ and $\mathrm{Hf}$ isotopic study of $\mathrm{Pa}-$ leozoic granitoids. I. Asian Earth Sci. 42:949-968.

Carroll, A. R.; Graham, S. A.; Hendrix, M. S.; Ying, D.; and Zhou, D. 1995. Late Paleozoic tectonic amalgamation of northwestern China: sedimentary record of the northern Tarim, northwestern Turpan, and southern Junggar basins. Geol. Soc. Am. Bull. 107:571-594.

Carroll, A. R.; Liang, Y.; Graham, S. A.; Xiao, X. C.; Hendrix, M. S.; Chu, J.; and McKnight, C. L. 1990. Junggar Basin, northwestern China: trapped late Paleozoic ocean. Tectonophysics 181:1-4.

Chen, B., and Jahn, B. M. 2004. Genesis of post-collisional granitoids and basement nature of the Junggar terrane, NW China: Nd-Sr isotope and trace element evidence. I. Asian Earth Sci. 23:691-703.

Chen, H. L.; Yang, S. F.; Li, Z. L.; Yu, X.; Xiao, W. J.; Yuan, C.; Lin, X. B.; and Li, J. L. 2006b. Zircon SHRIMP U-Pb chronology of Fuyun basic granulite and its tectonic 
significance in Altaid orogenic belt. Acta Petrol. Sin. 22:1351-1358 (in Chinese with English abstract).

Chen, H. L.; Yang, S. F.; Li, Z. L.; Yuan, C.; Xiao, W. J.; Li, J. L.; Yu, X.; and Lin, X. B. 2006a.Tectonic setting of mafic rocks in southern Altay orogenic belt and its geodynamic implication. Acta Petrol. Sin. 22:127-134 (in Chinese with English abstract).

Choulet, F.; Faure, M.; Cluzel, D.; Chen, Y.; Lin, W.; and Wang, B. 2012. From oblique accretion to transpression in the evolution of the Altaid collage: new insights from West Junggar, northwestern China. Gondwana Res. 21:530-547.

Cox, K. G. 1980. A model for flood basalt volcanism. I. Petrol. 21:629-650.

Defant, M. J., and Drummond, M. S. 1990. Derivation of some modern arc magmas by melting of young subducted lithosphere. Nature 347:662-665.

Eichelberger, J. 1978. Andesitic volcanism and crustal evolution. Nature 275:21-27.

Frey, F. A.; Green, D. H.; and Roy, R. D. 1978. Integrated models of basalt petrogenesis: a study of quarti tholeiites to olivine melilities from south eastern Australia utilizing geochemical and experimental petrological data. I. Petrol. 19:463-513.

Gao, J. F., and Zhou, M. F. 2013. Magma mixing in the genesis of the Kalatongke dioritic intrusion: implications for the tectonic switch from subduction to postcollision, Chinese Altay, NW China. Lithos 162/163: 236-250.

Geng, H.; Sun, M.; Yuan, C.; Xiao, W.; Xian, W.; Zhao, G.; Zhang, L.; Wong, K.; and Wu, F. 2009. Geochemical, $\mathrm{Sr}-\mathrm{Nd}$ and zircon U-Pb-Hf isotopic studies of Late Carboniferous magmatism in the West Junggar, Xinjiang: implications for ridge subduction? Chem. Geol. 266:364-389.

Green, D. H. 1975. Genesis of Archean peridotitic magmas and constraints on Archean geothermal gradients and tectonics. Geology 3:15-18.

Green, N. L. 2006. Influence of slab thermal structure on basalt source regions and melting conditions: REE and HFSE constraints form the Garibaldi volcanic belt, northern Cascadia subduction system. Lithos 87:23-49.

Griffin, W. L.; Pearson, N. J.; Belousova, E.; Jackson, S. E.; van Achterbergh, E.; O'Reilly, S. Y.; and Shee, S. R. 2000. The Hf isotope composition of cratonic mantle: LAM-MC-ICPMS analysis of zircon megacrysts in kimberlites. Geochim. Cosmochim. Acta 64:133-147.

Griffiths, R. W., and Campbell, I. H. 1991. Interaction of mantle plume heads with the Earth's surface and onset of small-scale convection. I. Geophys. Res. 96:18295-18310.

Han, B. F.; He, G. Q.; and Wang, S. G. 1999. Postcollisional mantle-derived magmatism, underplating and implication for the basement of the Jungger Basin. Sci. China 42:113-119.

Han, B. F.; Ji, J. Q.; Song, B.; Chen, L. H.; and Li, Z. 2004. SHRIMP zircon $\mathrm{U}-\mathrm{Pb}$ ages of Kalatongke no. 1 and Huangshandong Cu-Ni-bearing mafic-ultramafic complexes, North Xinjiang, and geological implications. Chin. Sci. Bull. 49:2424-2429.
Han, B. F.; Wang, S. G.; Jahn, B. M.; Hong, D. W.; Kagami, H.; and Sun, Y. L. 1997. Depleted-mantle source for the Ulungur River A-type granites from North Xinjiang, China: geochemistry and Nd-Sr isotopic evidence, and implications for Phanerozoic crustal growth. Chem. Geol. 138:135-159.

He, G. Q.; Han, B. F.; Yue, Y. J.; and Wang, J. H. 1990. Tectonic division and crustal evolution of Altay orogenic belt in China. Geosci. Xinjiang 2:9-20 (in Chinese with English abstract).

Helz, R. 1976. Phase relations of basalt in their melting ranges at $P_{\mathrm{H}_{2} \mathrm{O}}=5 \mathrm{~kb}$. 2. Melt compositions. I. Petrol. 17:139-193.

Hess, P. C. 1992. Phase equilibria constraints on the origin of ocean floor basalt. In Morgan, J. P.; Blackman, D. K.; and Sinton, J. M., eds. Mantle flow and melt generation at mid-ocean ridges. Am. Geophys. Union 71:67-102.

Jahn, B. M. 2004. The Central Asian Orogenic Belt and growth of the continental crust in the Phanerozoic. In Malpas, J.; Fletcher, C. J. N.; Ali, J. R.; and Aitchison, J. C., eds. Aspects of the tectonic evolution of China 226. Geol. Soc. Lond. Spec. Publ. 226:73-100.

Jahn, B. M.; Wu, F. Y.; and Chen, B., 2000a. Granitoids of the Central Asian Orogenic Belt and continental growth in the Phanerozoic. Geol. Soc. Am. Spec. Pap. 350:181-193.

2000b. Massive granitoid generation in Central Asia: $\mathrm{Nd}$ isotope evidence and implication for continental growth in the Phanerozoic. Episodes 23:82-92.

Johnson, K. T. M. 1994. Experimental cpx/ and garnet/ melt partitioning of REE and other trace elements at high pressures; petrogenetic implications. Mineral. Mag. 58:454-455.

Kelemen, P. B.; Hanghoj, K.; and Greene, A. R. 2003. One view of the geochemistry of subduction-related magmatic arcs, with an emphasis on primitive andesite and lower crust. In Rudnick, R. L., ed. Treatise on geochemistry (vol. 3). Amsterdam, Elsevier Pergamon, p. 593-659.

Khain, E. V.; Bibokova, E. V.; Kroner, A.; Zhuravlev, D. Z.; Sklyarov, E. V.; Fedotova, A. A.; and KravchenkoBerezhnoy, I. R. 2002. The most ancient ophiolites of the Central Asian fold belt: U-Pb and $\mathrm{Pb}-\mathrm{Pb}$ zircon ages for the Dunzhugur complex, Eastern Sayan, Siberia, and geodynamic implications. Earth Planet. Sci. Lett. 199:311-325.

Kovalenko, V. I.; Yarmolyuk, V. V.; Kovach, V. P.; Kotov, A. B.; Kozakov, I. K.; Sal'nikova, E. B.; and Larin, A. M. 2004. Isotope provinces, mechanisms of generation and sources of the continental crust in the Central Asian mobile belt: geological and isotopic evidence. I. Asian Earth Sci. 23:605-627.

Kröner, A.; Demoux, A.; Zack, T.; Rojas-Agramonte, Y.; Jian, P.; Tomurhuu, D.; and Barth, M. 2011. Zircon ages for a felsic volcanic rock and arc-related early Palaeozoic sediments on the margin of the Baydrag microcontinent, central Asian orogenic belt, Mongolia. I. Asian Earth Sci. 42:1008-1017. 
Kröner, A.; Kovach, V.; Belousova, E.; Hegner, E.; Armstrong, R.; Dolgopolova, A.; Seltmann, R.; et al. 2014. Reassessment of continental growth during the accretionary history of the Central Asian Orogenic Belt. Gondwana Res. 25:103-125.

Lehmann, J.; Schulmann, K.; Lexa, O.; Corsini, M.; Kröner, A.; Štípská, P.; Tomurhuu, D.; and Otgonbator, D. 2010. Structural constraints on the evolution of the Central Asian Orogenic Belt in SW Mongolia. Am. I. Sci. 310:575-628.

Levashova, N. M.; Kalugin, V. M.; Gibsher, A. S.; Yff, J.; Ryabinin, A. B.; Meert, J. G.; and Malone, S. J. 2010. The origin of the Baydaric microcontinent, Mongolia: constraints from paleomagnetism and geochronology. Tectonophysics 485:306-320.

Levashova, N. M.; Meert, J. G.; Gibsher, A. S.; Grice, W. C.; and Bazhenov, M. L. 2011. The origin of microcontinents in the Central Asian Orogenic Belt: constraints from paleomagnetism and geochronology. Precambrian Res. 185:37-54.

Li, C.; Zhang, M.; Fu, P.; Qian, Z.; Hu, P.; and Ripley, E. 2012. The Kalatongke magmatic Ni-Cu deposits in the Central Asian Orogenic Belt, NW China: product of slab window magmatism? Miner. Depos. 47:51-67.

Li, X. H. 1997. Geochemistry of the Longsheng Ophiolite from the southern margin of Yangtze Craton, SE China. Geochem. I. 31:323-337.

Li, X. H.; Li, Z. X.; Wingate, M. T. D.; Chung, S. L.; Liu, Y.; Lin, G. C.; and Li, W. X. 2006. Geochemistry of the 755 Ma Mundine Well dyke swarm, northwestern Australia: part of a Neoproterozoic mantle superplume beneath Rodinia? Precambrian Res. 146:1-15.

Li, Z. L.; Chen, H. L.; Yang, S. F.; Xiao, W. J.; and Tainosho, Y. 2004. Discovery of the basic granulite from the Altai area: evidence from mineralogy. Acta Petrol. Sin. 20: 1445-1455 (in Chinese with English abstract).

Li, Z. L.; Li, Y.; Chen, H. L.; Santosh, M.; Xiao, W. J.; and Wang, H. 2010. SHRIMP U-Pb zircon chronology of ultrahigh-temperature spinel-orthopyroxene-garnet granulite from south Altay orogenic belt, northwestern China. Island Arc 19:506-516.

Liang, X. R.; Wei, G. J.; Li, X. H.; and Liu, Y. 2003. Precise measurement of ${ }^{143} \mathrm{Nd} /{ }^{144} \mathrm{Nd}$ and $\mathrm{Sm} / \mathrm{Na}$ ratios using multiple-collectors inductively coupled plasma-mass spectrometer (MC-ICPMS). Geochimica 32:91-96 (in Chinese with English abstract).

Liu, Y.; Hu, Z.; Gao, S.; Günther, D.; Xu, J.; Gao, C.; and Chen, H. 2008. In situ analysis of major and trace elements of anhydrous minerals by LA-ICP-MS without applying an internal standard. Chem. Geol. 257:34-43.

Liu, Y.; Liu, H. C.; and Li, X. H. 1996. Simultaneous and precise determination of 40 trace elements in rock samples using ICP-MS. Geochimica 25:552-558.

Long, X. P.; Sun, M.; Yuan, C.; Xiao, W. J.; Lin, S. F.; Wu, F. Y.; Xia, X. P.; and Cai, K. D. 2007. U-Pb and Hf isotopic study of zircons from metasedimentary rocks in the Chinese Altai: implications for Early Paleozoic tectonic evolution. Tectonics 26:TC5015, doi:10.1029 /2007TC002128.
Long, X. P.; Yuan, C.; Sun, M.; Safonova, I.; Xiao, W. J.; and Wang, Y. J. 2012. Geochemistry and U-Pb detrital zircon dating of Paleozoic graywackes in East Junggar, NW China: insights into subduction-accretion processes in the southern Central Asian Orogenic Belt. Gondwana Res. 21:637-653.

Long, X. P.; Yuan, C.; Sun, M.; Xiao, W. J.; Zhao, G. C.; Wang, Y. J.; and Cai, K. D. 2010. Detrital zircon ages and $\mathrm{Hf}$ isotopes of the early Paleozoic Flysch sequence in the Chinese Altai, NW China: new constraints on depositional age, provenance and tectonic evolution. Tectonophysics 480:213-231.

Ludwig, K. R. 2003. User's manual for Isoplot 3.00: a geochronological toolkit for Microsoft Excel. Spec. Publ. 4a. Berkeley, Berkeley Geochronology Center.

Ma, C.; Xiao, W. J.; Windley, B. F.; Zhao, G.; Han, C.; Zhang, J., Luo, J.; and Li, C. 2012. Tracing a subducted ridge-transform system in a late Carboniferous accretionary prism of the southern Altaids: orthogonal sanukitoid dyke swarms in Western Junggar, NW China. Lithos 140/141:152-165.

Mao, J. W.; Pirajno, F.; Zhang, Z. H.; Chai, F. M.; Chen, S. P.; Yang, M. J.; and Zhang, C. Q. 2008. A review of the $\mathrm{Cu}-\mathrm{Ni}$ sulphide deposits in the Chinese Tianshan and Altay orogens (Xinjiang Autonomous Region, NW China): principal characteristics and ore forming processes. I. Asian Earth Sci. 32:184-203.

McKenzie, D., and O'Nions, R. K. 1991. Partial melt distribution from inversion of rare earth element concentrations. I. Petrol. 32:1021-1091.

Mossakovsky, A. A.; Ruzhentsev, S. V.; Samygin, S. G.; and Kheraskova, T. N. 1993. Central Asian fold belt: geodynamic evolution and history of formation. Geotektonika 6:3-33 (in Russian).

Patiño Douce, A. E. 1996. Effects of pressure and $\mathrm{H}_{2} \mathrm{O}$ content on the compositions of primary crustal melts. Trans. R. Soc. Edinb. Earth Sci. 87:11-21.

Petford, N., and Atherton, M. 1996. Na-rich partial melts from newly underplated basaltic crust: the Cordillera Blanca Batholith, Peru. I. Petrol. 37:1491-1521.

Pirajno, F.; Mao, J. W.; Zhang, Z. C.; Zhang, Z. H.; and Chai, F. M. 2008. The association of mafic-ultramafic intrusions and A-type magmatism in the Tian Shan and Altai orogens, NW China: implications for geodynamic evolution and potential for the discovery of new ore deposits. I. Asian Earth Sci. 32:165-183.

Rapp, R. P., and Watson, E. B. 1995. Dehydration melting of metabasalt at 8-32 kbar: implications for continental growth and crust-mantle recycling. I. Petrol. 36:891-932.

Rapp, R. P.; Watson, E. B.; and Miller, C. F. 1991. Partial melting of amphibolite/eclogite and the origin of Archaean trondhjemites and tonalites. Precambrian Res. 51:1-25.

Ren, J. S.; Wang, Z. X.; Chen, B. W.; Jiang, C. E.; and Niu, B. G. 1999. Tectonic map of China. Beijing, Geological Publishing House, scale 1:5000000.

Roberts, M. P., and Clemens, J. D. 1993. Origin of highpotassium, calc-alkaline, I-type granitoids. Geology 21: $825-828$. 
Rushmer, T. 1991. Partial melting of two amphibolites: contrasting experimental results under fluid absent conditions. Contrib. Mineral. Petrol. 107:41-59.

Schärer, E.; Munker, C.; and Mezger, K. 2001. Calibration of the lutetium-hafnium clock. Science 293:683687.

Sengör, A. M. C., and Natal'in, B. A. 1996. Paleotectonics of Asia: fragments of a synthesis. In Yin, A., and Harrison, T. M., eds. The tectonic evolution of Asia. Cambridge, Cambridge University Press, p. 486-640.

Sengör, A. M. C.; Natal'in, B. A.; and Burtman, V. S. 1993. Evolution of the Altaid tectonic collage and Palaeozoic crustal growth in Asia. Nature 364:299-307.

Singh, J., and Johannes, W. 1996. Dehydration melting of tonalites. 1. Beginning of melting. Contrib. Mineral. Petrol. 125:16-25.

Song, X. Y., and Li, X. R. 2009. Geochemistry of the Kalatongke Ni-Cu-(PGE) sulfide deposit, NW China: implications for the formation of magmatic sulfide mineralization in a postcollisional environment. Miner. Depos. 44:303-327.

Su, B. X.; Qin, K. Z.; Sakyi, P. A.; Li, X. H.; Yang, Y. H.; Sun, H.; Tang, D. M.; Liu, P. P.; Xiao, Q. H.; and Malaviarachchi, S. P. K. 2011. U-Pb ages and Hf-O isotopes of zircons from Late Paleozoic mafic-ultramafic units in the southern Central Asian Orogenic Belt: tectonic implications and evidence for an Early-Permian mantle plume. Gondwana Res. 20:516-531.

Sun, M.; Long, X. P.; Cai, K. D.; Jiang, Y. D.; Wang, B. Y.; Yuan, C.; Zhao, G. C.; Xiao, W. J.; and Wu, F. Y. 2009. Early Paleozoic ridge subduction in the Chinese Altai: insight from the marked change in zircon Hf isotopic composition. Sci. China Ser. D 52:1345-1358.

Sun, M.; Yuan, C.; Xiao, W. J.; Long, X. P.; Xia, X. P.; Zhao, G. C.; Lin, S. F.; Wu, F. Y.; and Kröner, A. 2008. Zircon $\mathrm{U}-\mathrm{Pb}$ and $\mathrm{Hf}$ isotopic study of gneissic rocks from the Chinese Altai: progressive accretionary history in the early to middle Paleozoic. Chem. Geol. 247:352383.

Sun, S. S., and McDonough, W. F. 1989. Chemical and isotopic systematics of oceanic basalts: implications for mantle composition and processes. In Saunders, A. D., and Norry, M. J., eds. Magmatism in the ocean basins. Geol. Soc. Lond. Spec. Publ. 42:315-345.

Tanaka, T.; Togashi, S.; Kamioka, H.; Amakawa, H.; Kagami, H.; and Hamamoto, T. 2000. JNdi-1: a neodymium isotopic reference in consistency with LaJolla neodymium. Chem. Geol. 168:279-281.

Tong, L. X.; Xu, Y. G.; Cawood, P. A.; Zhou, X.; Chen, Y. B.; and Liu, Z. 2014. Anticlockwise P-T evolution at $\sim 280 \mathrm{Ma}$ recorded from ultrahigh-temperature metapelitic granulite in the Chinese Altai orogenic belt, a possible link with the Tarim mantle plume? I. Asian Earth Sci. 94:1-11.

Tong, Y.; Wang, T.; Siebel, W.; Hong, D. W.; and Sun, M. 2012. Recognition of early Carboniferous alkaline granite in the southern Altai orogen: post-orogenic processes constrained by $\mathrm{U}-\mathrm{Pb}$ zircon ages, $\mathrm{Nd}$ isotopes, and geochemical data. Int. I. Earth Sci. 101:937-950.
Wan, B.; Xiao, W. J.; Windley, B. F.; and Yuan, C. 2013. Permian hornblende gabbro in the Chinese Altai from a subduction-related hydrous parent magma, not from the Tarim mantle plume. Lithosphere 5:290-299.

Wang, T.; Hong, D. W.; Jahn, B. M.; Tong, Y.; Wang, Y. B.; Han, B. F.; and Wang, X. X. 2006. Timing, petrogenesis, and setting of Palaeozoic synorogenic intrusions from the Altai Mountains, northwest China: implications for the tectonic evolution of an accretionary orogen. I. Geol. 114:735-751.

Wang, Y. X.; Mooney, W. D.; Yuan, X. C.; and Coleman, R. G. 2003. The crustal structure from the Altai Mountains to the Altyn Tagh fault, northwest China. J. Geophys. Res. 108:2322, doi:10.1029/2001JB000552.

Wei, G. J.; Liang, X. R.; Li, X. H.; and Liu, Y. 2002. Precise measurement of $\mathrm{Sr}$ isotopic compositions of liquid and solid base using (LA) MC-ICP-MS. Geochimica 31:295-305.

Wilhem, C.; Windley, B. F.; and Stampfli, G. M. 2012. The Altaids of Central Asia: a tectonic and evolutionary innovative review. Earth-Sci. Rev. 113:303-341.

Windley, B. F.; Alexeiev, D.; Xiao, W. J.; Kröner, A.; and Badarch, G. 2007. Tectonic models for accretion of the Central Asian Orogenic Belt. I. Geol. Soc. Lond. 164:31-47.

Windley, B. F.; Kröner, A.; Guo, J.; Qu, G.; Li, Y.; and Zhang, C. 2002. Neoproterozoic to Paleozoic geology of the Altai orogen, NW China: new zircon age data and tectonic evolution. I. Geol. 110:719-739.

Wolf, M. B., and Wyllie, P. J. 1994. Dehydration-melting of amphibolite at 10 kbar: the effects of temperature and time. Contrib. Mineral. Petrol. 107:369-383.

Woodhead, J. D.; Hergt, J.; Shelley, M.; Eggins, S.; and Kemp, R. 2004. Zircon Hf-isotope analysis with an excimer laser, depth profiling, ablation of complex geometries, and concomitant age estimation. Chem. Geol. 209:121-135

Xia, X. P.; Sun, M.; Geng, H. Y.; Sun, Y. L.; Wang, Y. J.; and Zhao, G. C. 2011. Quasi-simultaneous determination of $\mathrm{U}-\mathrm{Pb}$ and $\mathrm{Hf}$ isotope compositions of zircon by excimer laser-ablation multiple-collector ICPMS. I. Anal. At. Spectrom. 26:1868-1871.

Xiao, W. J.; Han, C. M.; Yuan, C.; Sun, M.; Lin, S. F.; Chen, H. L.; Li, Z. L.; Li, J. L.; and Sun, S. 2008. Middle Cambrian to Permian subduction-related accretionary orogenesis of North Xinjiang, NW China: implications for the tectonic evolution of Central Asia. I. Asian Earth Sci. 32:102-117.

Xiao, W. J.; Huang, B. C.; Han, C. M.; Sun, S.; and Li, J. L. 2010. A review of the western part of the Altaids: a key to understanding the architecture of accretionary orogens. Gondwana Res. 18:253-273.

Xiao, W. J., and Santosh, M. 2014. The western Central Asian Orogenic Belt: a window to accretionary orogenesis and continental growth. Gondwana Res. 25:1429-1444.

Xiao, W. J.; Windley, B. F.; Allen, M. B.; and Han, C. M. 2013. Paleozoic multiple accretionary and collisional tectonics of the Chinese Tianshan orogenic collage. Gondwana Res. 13:1316-1341.

Xiao, W. J.; Windley, B. F.; Badararch, G.; Sun, S.; Li, J.; Qin, K.; and Wang, Z. 2004. Palaeozoic accretionary 
and convergent tectonics of the southern Altaids: implications for the growth of central Asia. I. Geol. Soc. Lond. 161:1-4.

Xiao, W. J.; Windley, B. F.; Sun, S.; Li, J.; Huang, B. C.; Han, C. M.; Yuan, C.; Sun, M.; and Chen, H. L. 2015. A tale of amalgamation of three Permo-Triassic collage systems in Central Asia: oroclines, sutures, and terminal accretion. Annu. Rev. Earth Planet. Sci. 43:16.1-16.31.

Xiao, W. J.; Windley, B. F.; Yuan, C.; Sun, M.; Han, C. M.; Lin, S. F.; Chen, H. L.; et al. 2009. Paleozoic multiple subduction-accretion processes of the southern Altaids. Am. I. Sci. 309:221-270.

Xiao, Y.; Zhang, H. F.; Shi, J. A.; Su, B. X.; Sakyi, P. A.; Hu, Y.; and Zhang, Z. 2011. Late Paleozoic magmatic record of East Junggar, NW China and its significance: implication from zircon $\mathrm{U}-\mathrm{Pb}$ dating and $\mathrm{Hf}$ isotope. Gondwana Res. 20:532-542.

Xu, Q. Q.; Ji, J. Q.; Zhao, L.; Gong, J. F.; and Zhou, J. 2013. Tectonic evolution and continental crust growth of Northern Xinjiang in northwestern China: remnant ocean model. Earth Sci. Rev. 126:178-205.

Xu, X. W.; Li, X. H.; Jiang, N.; Li, Q. L.; Qu, X.; Yang, Y. H.; Zhou, G.; and Dong, L. H. 2015. Basement nature and origin of the Junggar terrane: new zircon U-Pb-Hf isotope evidence from Paleozoic rocks and their enclaves. Gondwana Res. 28:288-310.

Yakubchuk, A. 2004. Architecture and mineral deposit settings of the Altaid orogenic collage: a revised model. I. Asian Earth Sci. 23:761-779.

Yin, J. Y.; Yuan, C.; Sun, M.; Long, X. P.; Zhao, G. C.; Wong, K. P.; Geng, H. Y.; and Cai, K. D. 2010. Late Carboniferous high-Mg dioritic dikes in Western Junggar, NW China: geochemical features, petrogenesis and tectonic implications. Gondwana Res. 17:145-152.

Yuan, C.; Sun, M.; Xiao, W. J.; Li, X. H.; Chen, H. L.; Lin, S. F.; Xia, X. P.; and Long, X. P. 2007. Accretionary orogenesis of the Chinese Altai: insights from Paleozoic granitoids. Chem. Geol. 242:22-39.

Yuan, C.; Sun, M.; Xu, Y. G.; Zhao, G. C.; Xiao, W. J.; Long, X. P.; and Yin, J. Y. 2011. Oceanic lithospheric mantle beneath the continental crust of the Chinese Altai. I. Geol. Soc. 168:995-1000.

Zhang, C. L.; Zou, H. B.; Yao, C. Y.; and Dong, Y. G. 2014. Origin of Permian gabbroic intrusions in the southern margin of the Altai Orogenic belt: a possible link to the Permian Tarim mantle plume? Lithos 204:112124.

Zhang, H. X.; Niu, H. C.; Sato, H.; Shan, Q.; Yu, X. Y.; Ito, J.; and Zhang, Q. 2004. Late Paleozoic adakite and Nbenriched basalt from Northern Xinjiang: evidence for the southward subduction of the Paleo-Asian Ocean. Geol. J. China Univ. 10:106-113.

Zhang, H. X.; Niu, H. C.; Terada, K.; Yu, X. Y.; Sato, H.; and Ito, J. 2003. Zircon SHRIMP U-Pb dating on plagiogranite from Kuerti ophiolite in Altay, North Xiniiang. Chin. Sci. Bull. 48:2231-2235.

Zhang, J.; Sun, M.; Schulmann, K.; Zhao, G. C.; Wu, Q. H.; Jiang, Y. D.; Guy, A.; and Wang, Y. J. 2015. Distinct deformational history of two contrasting tectonic domains in the Chinese Altai: their significance in understanding accretionary orogenic process. I. Struct. Geol. 73:64-82.

Zhang, Z. C.; Mao, J. W.; Chai, F. M.; Yan, S. H.; Chen, B. L.; and Pirajno, F. 2009. Geochemistry of the Permian Kalatongke mafic intrusions, Northern Xinjiang, northwest China: implications for the genesis of magmatic Ni-Cu sulfide deposits. Econ. Geol. 104: 185-203.

Zonenshain, L. P.; Kuzmin, M. I.; and Natapov, L. M. 1990. Geology of the USSR: a plate-tectonic synthesis. Washington, D.C., Am. Geophys. Union, doi:10.1002 /9781118669884.fmatter. 